\title{
MICROCLIMA E PRODUÇÃO DE GÉRBERA EM AMBIENTES PROTEGIDOS COM DIFERENTES TIPOS DE COBERTURA
}

\author{
Cristiane Guiselini
}

Dissertação apresentada à Escola Superior de Agricultura "Luiz de Queiroz", Universidade de São Paulo, para obtenção do título de Mestre em

Agronomia, Área de Concentração: Física do Ambiente Agrícola.

PIRACICABA

Estado de São Paulo - Brasil

Novembro - 2002 


\section{MICROCLIMA E PRODUÇÃO DE GÉRBERA EM AMBIENTES PROTEGIDOS COM DIFERENTES TIPOS DE COBERTURA}

\section{CRISTIANE GUISELINI}

Engenheira Agrônoma

Orientador: Prof. Dr. PAULO CESAR SENTELHAS

Dissertação apresentada à Escola Superior de Agricultura "Luiz de Queiroz", Universidade de São Paulo, para obtenção do título de Mestre em Agronomia, Área de Concentração: Física do Ambiente Agrícola.

PIRACICABA

Estado de São Paulo - Brasil

Novembro - 2002 


\title{
Dados Internacionais de Catalogação na Publicação (CIP) DIVISÃO DE BIBLIOTECA E DOCUMENTAÇÃO - ESALQ/USP
}

\author{
Guiselini, Cristiane \\ Microclima e produção de gérbera em ambientes protegidos com \\ diferentes tipos de cobertura / Cristiane Guiselini. - - Piracicaba, 2002. \\ 53 p. : il. \\ Dissertação (mestrado) - - Escola Superior de Agricultura Luiz de \\ Queiroz, 2002. \\ Bibliografia. \\ 1. Estufa 2. Gérbera 3. Microclima 4. Plasticultura 5. Sombreamento I. \\ Título
}

CDD 635.9355 
Ao meu "Sol" Héliton Pandorfi pelo amor, carinho, companheirismo e cumplicidade 


\section{AGRADECIMENTOS}

A Deus e minha família pela minha vida e pela força nos momentos em que mais precisei para vencer os obstáculos surgidos durante esse percurso.

À Escola Superior de Agricultura "Luiz de Queiroz" e ao curso de Física do Ambiente Agrícola pelas tantas oportunidades oferecidas.

Ao Professor Dr. Paulo Cesar Sentelhas, pela orientação, amizade, confiança, incentivo e entusiasmo na execução desse trabalho, responsável pelo meu crescimento pessoal e científico.

Aos professores do Programa de Pós-Graduação em Física do Ambiente Agrícola, pelos ensinamentos e pela oportunidade de realização do curso.

Aos professores Luiz Roberto Angelocci, Quirijn de Jong Van Lier e Nilson Augusto Villa Nova, pelos ensinamentos, sugestões para a melhoria e engrandecimento deste trabalho.

À Professora Sônia Maria Piedade, pelo auxílio na definição e execução das análises estatísticas.

Ao CNPq, Conselho Nacional de Desenvolvimento Científico e Tecnológico, pela concessão da bolsa de estudos.

Aos alunos de graduação Rafael e Rodrigo pelo apoio e entusiasmo na execução desse trabalho.

Ao Sr. Henrique Tonino e Kelcinele Taranto, Solpack Ltda, Eng. Agrônomo Emerson Steinberg, Syngenta Seeds LTDA e Eng. Agrônomo Carlos de Carvalho Hanada, Jardino Ind. e Com. de Estufas Agrícolas Ltda, pela atenção, confiança, sugestões e colaboração para o desenvolvimento desse trabalho, viabilizando a instalação e execução do experimento de campo.

Aos colegas de curso Angélica Prela, Luciano Quaglia, José Eduardo B. de A. Monteiro, Rogério Cichota, Fábio Ricardo Marin, Alailson Venceslau Santiago, Alexandre Ortega Gonçalves, Beatriz Ibet Lozada Garcia, Evandro Zanini Righi, Felipe Gustavo Pilau e Gustavo Bastos Lyra pela amizade e apoio direto e indireto na realização desse trabalho e convívio e amizade durante a realização do curso. 
Às minha amigas Alexandra e Giuliana pela amizade incondicional, conselhos e companheirismo.

A todas as pessoas que, direta ou indiretamente, contribuíram para realização deste trabalho. 


\section{SUMÁRIO}

Página

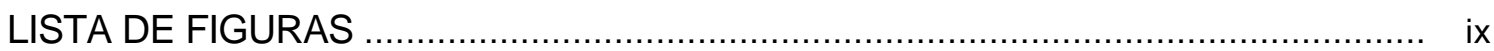

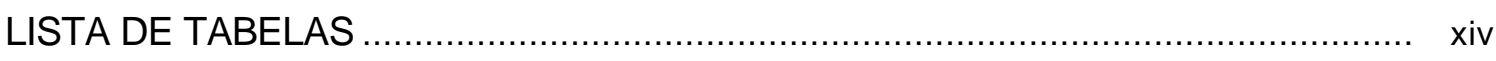

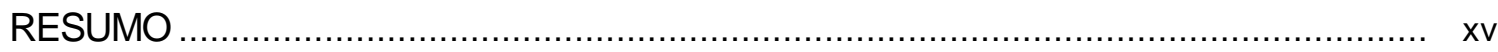

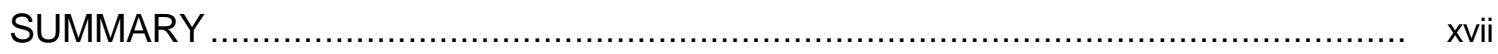

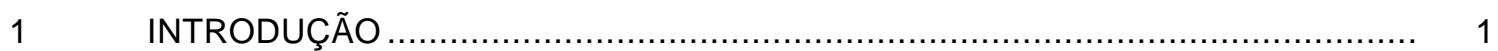

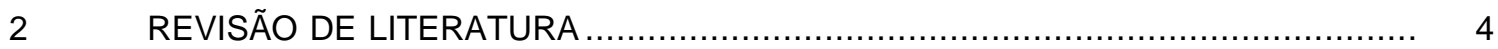

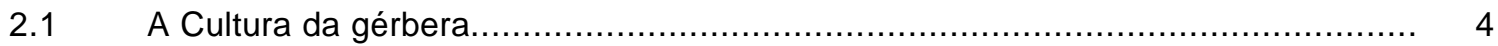

2.2 Microclima em Ambientes Protegidos ....................................................... 5

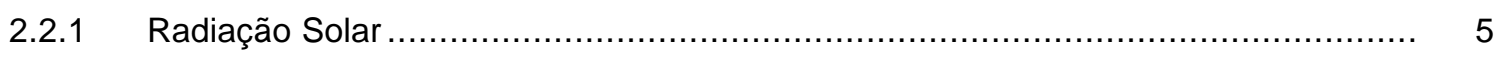

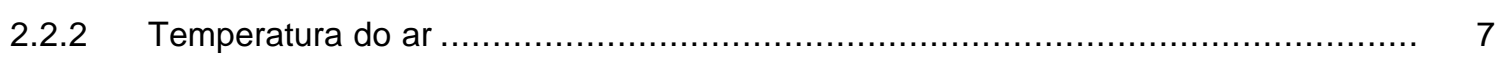

2.2.3 Umidade Relativa do ar ........................................................................ 9

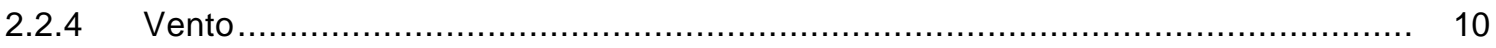

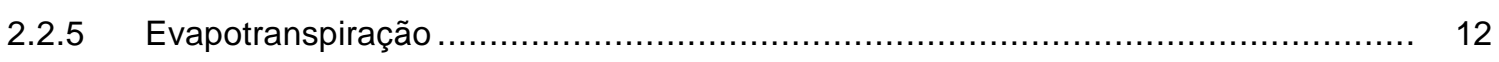

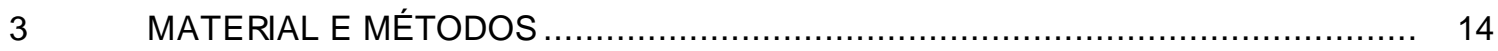

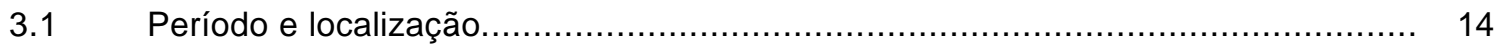

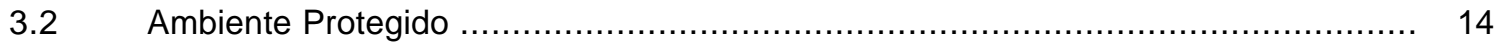

3.3 Instalação e Condução da Cultura da Gérbera ........................................... 16

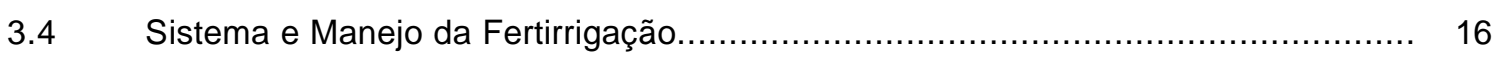

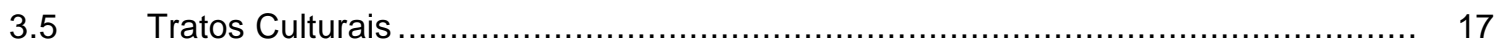

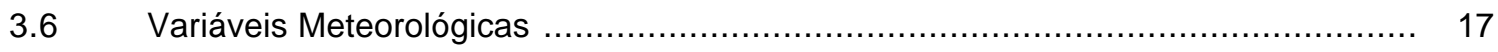

3.6.1 Temperatura e Umidade Relativa do ar ................................................. 17

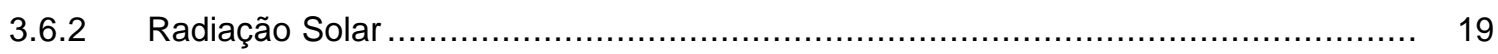

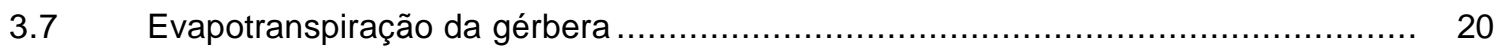

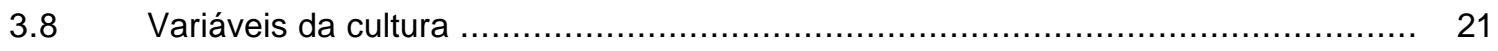

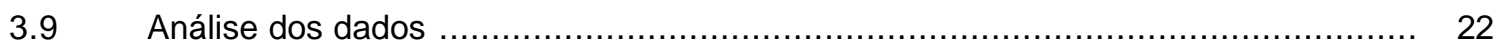

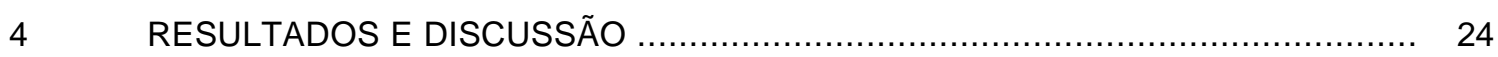

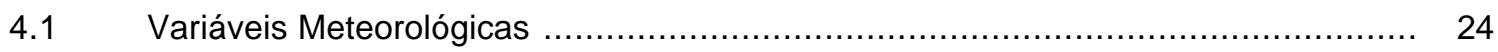

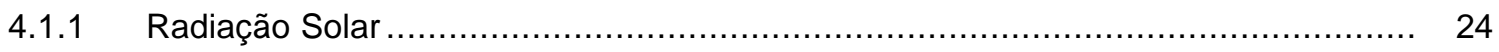




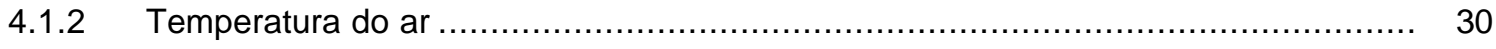

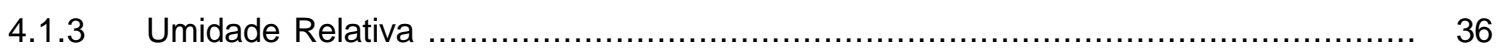

4.1.4 Evapotranspiração da gérbera ............................................................. 37

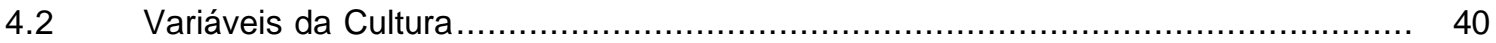

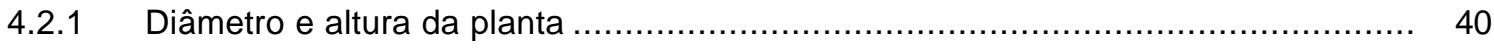

4.2.2 Número de folhas e botões florais........................................................ 42

4.2.3 Diâmetro do capítulo e altura da haste ......................................................... 45

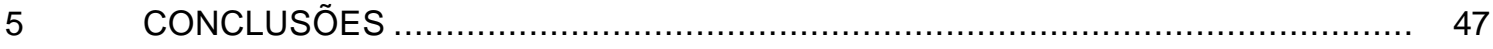

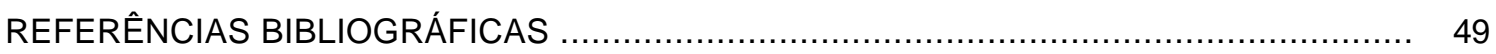




\section{LISTA DE FIGURAS}

Página

1 Gerbera jamesonii - Gérbera

2 Representação esquemática dos ambientes protegidos, suas dimensões e os tratamentos adotados: T1 - plástico leitoso; T2 - plástico leitoso + malha termorefletora e T3 - plástico leitoso + malha preta.

3 Vista lateral do ambiente protegido, com malha de sombreamento preta (50\%) nas paredes.

4 Vista interna dos ambientes protegidos cultivados com Gérbera, sendo T1 plástico leitoso, T2 - plástico leitoso + malha termo-refletora e T3 - plástico leitoso + malha preta.

5 Representação esquemática da disposição das bancadas e dos vasos no interior do ambiente protegido.

6 Representação esquemática do ambiente protegido com as bancadas de vasos e os instrumentos meteorológicos (detalhe): Radiação global $(\mathrm{Qg})$, radiação fotossinteticamente ativa (RFA), Temperatura de bulbo seco (T) e temperatura de bulbo úmido (Tu) (ventilado) e Sistema automático de aquisição de dados.

7 Instrumentos meteorológicos instalados em cada tratamento: radiação solar global $(\mathrm{Qg})$, radiação fotossinteticamente ativa (RFA), temperatura de bulbo seco $(\mathrm{T})$ e temperatura de bulbo úmido (Tu) (psicrômetro ventilado).

8 Calibração dos sensores CM3 e Li200, para medida da radiação solar global, tendo-se como referência o sensor PSP-Eppley

9 Calibração dos sensores LI190SB do tipo Quantum, para a medida da radiação fotossinteticamente ativa, tendo-se como referência o sensor PSP-Eppley com filtro para a faixa espectral de $697 \mathrm{~nm}$. 
10 Balança de precisão utilizada para a pesagem dos vasos na determinação da evapotranspiração da Gérbera.

11 Variáveis da cultura: (a) diâmetro da planta, dp, (b) altura da planta, ap, (c) altura da haste, ah e (d) diâmetro do capítulo, dc.

12 Representação esquemática do delineamento experimental utilizado no experimento. Os círculos representam os vasos, sendo os círculos cheios os vasos amostrados para avaliação da cultura.

13 Variação diária da radiação solar global $(\mathrm{Qg})$ no decorrer do período experimental, nos três ambientes protegidos (plástico leitoso, plástico leitoso + termo refletora e plástico leitoso + malha preta) e na estação meteorológica (ambiente externo).

14Variação diária da radiação fotossinteticamente ativa (RFA) no decorrer do período experimental, nos três ambientes protegidos (plástico leitoso, plástico leitoso + termo refletora e plástico leitoso + malha preta) e na estação meteorológica (ambiente externo).

15 Variação horária da radiação solar global $(\mathrm{Qg})$, para um dia de céu limpo (17/04), nos três ambientes protegidos (plástico leitoso, plástico leitoso + malha termo refletora e plástico leitoso + malha preta) e na estação meteorológica (ambiente externo).

16 Variação horária da radiação fotossinteticamente ativa (RFA), para um dia de céu limpo (17/04), nos três ambientes protegidos (plástico leitoso, plástico leitoso + malha termo-refletora e plástico leitoso + malha preta) e na estação meteorológica (ambiente externo).

17 Variação horária da radiação solar global $(\mathrm{Qg})$, para um dia nublado (30/04), nos três ambientes protegidos (plástico leitoso, plástico leitoso + malha termorefletora e plástico leitoso + malha preta) e na estação meteorológica (ambiente externo)

18 Variação horária da radiação fotossinteticamente ativa (RFA), para um dia nublado (30/04), nos três ambientes protegidos (plástico leitoso, plástico leitoso + malha termo-refletora e plástico leitoso + malha preta) e na estação meteorológica (ambiente externo). 
19 Variação diária da radiação solar global $(\mathrm{Qg})$ e da fotossinteticamente ativa (RFA), nos três ambientes protegidos: plástico leitoso (a), plástico leitoso + malha termo-refletora (b), plástico leitoso + malha preta (c) e na estação meteorológica (ambiente externo) (d), no decorrer do período experimental.....

20 Participação percentual da radiação solar global $(\mathrm{Qg})$ em radiação fotossinteticamente ativa (RFA) e radiação ultra-violeta e infravermelho próximo (UV+IVP) nos três ambientes protegidos: (a) plástico leitoso, (b) plástico leitoso + termo-refletora, (c) plástico leitoso + malha preta e na (d) estação meteorológica (ambiente externo).

21 Relação entre a radiação fotossinteticamente ativa e a radiação solar global nos ambientes cobertos por: plástico leitoso (a), plástico leitoso + malha termorefletora (b), plástico leitoso + malha preta (c) e na estação meteorológica (ambiente externo) (d).

22 Variação diária da temperatura média do ar $(\mathrm{T})$, no decorrer do período experimental, nos três ambientes protegidos (plástico leitoso, plástico leitoso + malha termo-refletora e plástico leitoso + malha preta) e na estação meteorológica (ambiente externo).

23 Variação horária da temperatura do ar, (a) em um dia de céu limpo (17/04, n=10 h. $d^{-1}$ ) e (b) em um dia nublado (30/04, $n=4,2$ h. $d^{-1}$ ), nos três ambientes protegidos: plástico leitoso, plástico leitoso + malha termo-refletora e plástico leitoso + malha, preta e na estação meteorológica (ambiente externo).

24 Relação entre a temperatura do ar em ambiente coberto com plástico leitoso (T1) e a temperatura do ar na estação meteorológica (T externo), na escala de 15 min ao longo do período experimental.

25 Relação entre a temperatura do ar no ambiente coberto com plástico leitoso + malha termo-refletora (T2) e a temperatura do ar na estação meteorológica ( $T$ externo), na escala de 15 min ao longo do período experimental.

26 Relação entre a temperatura do ar no ambiente coberto com plástico leitoso + malha preta (T3) e a temperatura do ar na estação meteorológica (T externo), na escala de $15 \mathrm{~min}$ ao longo do período experimental. 
27 Relação entre a temperatura do ar dos tratamentos e a temperatura do ar externa: (a), (c) e (e) Temperatura do ar diurna para os ambientes cobertos com plástico leitoso, plástico leitoso + malha termo-refletora e plástico leitoso + malha preta, respectivamente; (b), (d) e (f) temperatura do ar noturna para os tratamentos cobertos plástico leitoso, plástico leitoso + malha termo refletora e plástico leitoso + malha preta, respectivamente.

28 Variação da umidade relativa média (UR), no decorrer do período experimental, nos ambientes protegidos (plástico leitoso, plástico leitoso + malha termo refletora e plástico leitoso + malha preta) e na estação meteorológica (ambiente externo)

29 Variação horária da umidade relativa do ar no dia 24/05 nos ambientes protegidos: plástico leitoso, plástico leitoso + malha termo-refletora e plástico leitoso + malha preta, e na estação meteorológica (ambiente externo).

30 Variação horária: (a) da pressão de saturação (es) e (b) pressão atual de vapor (ea), no dia 24/05, nos ambientes protegidos: plástico leitoso, plástico leitoso + malha termo-refletora e plástico leitoso + malha preta, e na estação meteorológica (ambiente externo).

31 Variação horária da evapotranspiração da Gérbera, no dia 17/04, nos tratamentos: plástico leitoso, plástico leitoso + malha termo-refletora e plástico leitoso + malha preta.

32 Variação horária da evapotranspiração da Gérbera, no dia 10/05, nos tratamentos: plástico leitoso, plástico leitoso + malha termo-refletora e plástico leitoso + malha preta.

33 Variação horária da evapotranspiração da Gérbera, no dia 18/05, nos tratamentos: plástico leitoso, plástico leitoso + malha termo-refletora e plástico leitoso + malha preta.

34 Diâmetro médio (a) e altura média das plantas de Gérbera (b) nos ambientes protegidos: plástico leitoso, plástico leitoso + malha termo-refletora e plástico leitoso + malha preta, durante o período avaliado.

35 Número médio de folhas (a) e de botões florais (b) das plantas de Gérbera nos ambientes protegidos: plástico leitoso, plástico leitoso + malha termo-refletora e plástico leitoso + malha preta, durante o período avaliado. 
36 Desenvolvimento da Gérbera jamesonii, cultivadas em ambientes protegidos:

(a) plástico leitoso, (b) plástico leitoso + malha termo-refletora e (c) plástico leitoso + malha preta, após 16 semanas.

37 Diâmetro médio do capítulo (a) e altura média da haste (b) das plantas de Gérbera, nos ambientes protegidos: plástico leitoso, plástico leitoso + malha termo-refletora e plástico leitoso + malha preta, durante o período avaliado. 


\section{LISTA DE TABELAS}

1 Quantidade de flores e plantas ornamentais comercializadas no período de 1997 a 1999. Adaptado de Aki (1999).

2 Recomendação de fertirrigação para Gerbera jamesonii, caixa A e caixa B.

3 Evapotranspiração média da Gérbera $\left(\mathrm{mm}^{-1} \mathrm{~d}^{-1}\right)$, em cada ambiente protegido (plástico leitoso, plástico leitoso + malha termo-refletora e plástico leitoso + malha preta) nos dias 27/04, 10/05 e 18/05. Valores entre parentes representam o desvio padrão

4 Correlação entre a evapotranspiração diária da Gérbera em cada ambiente protegido: plástico leitoso (ET1), plástico leitoso + malha termo-refletora (ET2) e plástico leitoso + malha preta (ET3); e os elementos meteorológicos: temperatura média diária (Tmed), radiação solar global $(\mathrm{Qg})$, umidade relativa (UR) e déficit de saturação de vapor d'água $(\Delta \mathrm{e})$......

5 Diâmetro médio das planta de Gérbera, nos três ambientes protegidos.

6 Altura média das plantas de Gérbera nos três ambientes protegidos.

7 Número médio de folhas da plantas de Gérbera nos três ambientes protegidos.

8 Número médio de botões florais das plantas de Gérbera nos três ambientes protegidos.

9 Diâmetro médio do capítulo nos três ambientes protegidos. 46

10 Altura média da haste nos três ambientes protegidos. 46 


\title{
MICROCLIMA E PRODUÇÃO DE GÉRBERA EM AMBIENTES PROTEGIDOS COM DIFERENTES TIPOS DE COBERTURA
}

\author{
AUTORA: CRISTIANE GUISELINI \\ ORIENTADOR: PROF. DR. PAULO CESAR SENTELHAS
}

\section{RESUMO}

O objetivo deste trabalho foi avaliar a influência de ambientes cobertos com filme de polietileno branco leitoso e diferentes malhas de sombreamento (Termo-refletora $-50 \%$ e Preta - 50\%) nas seguintes variáveis ambientais: irradiância solar global, irradiância fotossinteticamente ativa, temperatura e umidade relativa do ar e evapotranspiração, e de seus respectivos microclimas no crescimento, no desenvolvimento e na qualidade da Gerbera jamesonii (Gérbera). O experimento foi realizado entre o outono e o inverno de 2002, junto à área experimental do Departamento de Ciências Exatas, da E.S.A. "Luiz de Queiroz", Universidade de São Paulo, em Piracicaba, SP. Foi instalado um ambiente protegido, subdividido em três partes iguais. Um dos ambientes era coberto apenas pelo plástico leitoso (T1), enquanto os outros dois possuíam, ainda, malhas de sombreamento, que foram instaladas internamente, à altura do pé direito, sendo um com malha termo-refletora (Alumitela) (T2) e outro com malha preta (T3), ambas com $50 \%$ de sombreamento, fabricadas pela Solpack Ltda. Os sensores foram instalados no centro de cada ambiente protegido (sub-divisão) e em uma estação meteorológica automatizada, a $100 \mathrm{~m}$ do experimento, para coleta dos dados meteorológicos externos. Os ambientes protegidos afetaram os elementos meteorológicos diminuindo a radiação solar, a umidade relativa do ar durante o período diurno e a evapotranspiração das planta de Gérbera e aumentando a temperatura do ar. As transmitâncias médias da radiação solar pelas coberturas (plástico leitoso, plástico leitoso + malha termo-refletora e plástico leitoso + malha preta) foram, respectivamente 23,11 e $7 \%$. As temperaturas médias diárias do ar dentro dos ambientes protegidos foram cerca de $6^{\circ} \mathrm{C}$ 
maiores no ambiente coberto pelo plástico leitoso e $3^{0} \mathrm{C}$ maiores nos ambientes cobertos pelo plástico leitoso associado às malhas de sombreamento quando comparadas as temperaturas externas. Os tipos de cobertura, em função do microclima proporcionado, afetaram o desenvolvimento das plantas de Gérbera. $O$ crescimento foi mais rápido sob o plástico leitoso e mais lento sob o plástico leitoso + malha preta. As plantas de Gérbera cultivadas sob os ambientes protegidos cobertos pelo plástico leitoso e pelo plástico leitoso + malha termorefletora atenderam æ̀̀ exigências quanto ao número de botões florais. Isso não ocorreu no ambiente sob o plástico leitoso + malha preta. Quanto a altura da haste, as plantas cultivadas em ambiente protegido não apresentou valores médios superiores ao mínimo exigido, de $10 \mathrm{~cm}$. Os microclimas proporcionados pelas coberturas constituídas por plástico leitoso e plástico leitoso + termo-refletora promoveram condições adequadas para o cultivo da Gérbera, durante o período entre o outono e o inverno. No entanto não pode-se afirmar que tais condições sejam representativas para todas as estações do ano, recomendando-se estudos futuros comparandose diferentes materiais de cobertura em diferentes épocas do ano, visando um melhor entendimento do microclima na produção comercial de Gérbera. 


\title{
MICROCLIMATE AND GERBERA GROWTH UNDER DIFFERENT GREENHOUSE COVERS
}

\author{
AUTHOR: CRISTIANE GUISELINI \\ AdVISER: PROF. DR. PAULO CESAR SENTELHAS
}

\section{SUMMARY}

The objective of this work was to evaluate the influence of white polyethylene as a greenhouse cover and its association with different shading screens (thermal screen and black screen) on the following environmental elements: incoming solar radiation $(\mathrm{Qg})$, photosynthetically active radiation (PAR), temperature $(T)$, relative humidity $(R H)$ and evapotranspiration (ET) and also to evaluate the effects of the different microclimatic conditions on the growth, development and quality of Gerbera Jamesonii. The experiment was carried out between late Autumn and Winter of 2002 at the experimental area of the Exact Sciences Departament, Agricultural College "Luiz de Queiroz", at the University of São Paulo, in Piracicaba, State of São Paulo, Brazil. A greenhouse was installed, sub-divided into three parts. One of them was covered just with white polyethylene (T1), while the others had, yet, shading screens, that were installed within the greenhouse, being one covered with a thermal screen (Alumitela) (T2) and the other one with a black screen (T3), both with $50 \%$ of shading, manufactured by Solpack Ltda. The meteorological sensors were installed in the center of each sub-division of the greenhouse and an automatic weather station was located at $100 \mathrm{~m}$ from the experimental area, to collect external meteorological data. The covers in the greenhouse affected the microclimate, decreasing $\mathrm{Qg}, \mathrm{PAR}, \mathrm{RH}$ and ET and increasing $\mathrm{T}$. The average transmission of solar radiation by the covers (white polyethylene, white polyethylene + thermal screen and white polyethylene + black screen) were, respectively, 23, 11 and $7 \%$. The mean daily air temperatures within the greenhouse were about $6 \mathrm{C}$ higher in the white polyethylene and $3^{\circ} \mathrm{C}$ higher in the environments covered by white polyethylene associated with the shading 
screens in comparison to the external temperatures. The types of covers, forming different microclimates, affected the growth and development of Gerbera plants. The growth was faster under the white polyethylene and slower under the white polyethylene associated with black screen. The plants cultivated under he greenhouse covered with white polyethylene and with white polyethylene associated with thermal screen filled the requirements in relation to the number of flower buttons. However, the same was not observed in the environment covered with white polyethylene associated with black screen. About the stem size, all the cultivated plants under all environmental conditions not presented the minimum required value $(10 \mathrm{~cm})$. In general, the microclimate influenced by the different covers offered adequated conditions for the cultivation of Gerbera, during autumn and winter periods. However, it is not possible to be sure that these conditions are representative for the whole year stations, being recommended forward studies comparing different cover materials on different periods of the year, searching for a better comprehension of the microclimate influence on the commercial production of Gerbera. 


\section{INTRODUÇÃO}

A área mundial total coberta por estufas é de aproximadamente 200 mil hectares (Hanafi \& Papasolomontos, 1999). No Brasil, a área cultivada sob plástico é de cerca de 2 mil hectares. Apenas no Estado de São Paulo, de acordo com levantamento realizado em 1995, pela Associação dos Engenheiros Agrônomos, havia 897 hectares de estufas, 59\% dos quais destinavam-se à produção de hortaliças e $39 \%$ à produção de plantas ornamentais (FNP Consultoria \& Comércio, 1999).

O mercado brasileiro de flores e plantas ornamentais movimenta em torno de $R \$ 1$ bilhão ao ano e possui uma taxa de crescimento anual de $20 \%$, podendo ser considerado um dos maiores de toda a economia brasileira, com uma crescente parte desse total, destinando-se à exportação (Arruda, 1996). Segundo Guimarães et al. (2000), em entrevista realizada junto a Sérgio Pupo Moreno, Presidente do Instituto Brasileiro de Flores (Ibraflor), entidade que une associações, produtores e profissionais do setor, a floricultura gera cerca de $R \$ 1,5$ bilhão ao ano e arrecada com a exportação um valor de aproximadamente US\$ 12 milhões, valor este considerado muito aquém do seu potencial.

Em Outubro de 2000 foi assinado o convênio entre o IBRAFLOR e a Agência de Promoção de Exportações (APEX), o qual tem como principal objetivo ampliar as exportações brasileiras de flores e plantas ornamentais, passando dos atuais US $\$ 13$ milhões para US $\$ 80$ milhões ao ano (IBRAFLOR, 2001). Considerando, ainda, o mercado interno brasileiro, somente as classes A, B e C (alta), grupo que pode ser comparado às populações médias dos 
países desenvolvidos pode chegar a um consumo estimado de US $\$ 10,00$ per capita/ano. Isto representa uma demanda potencial de crescimento de pelo menos 5 vezes o mercado atual (Castro, 1998). A Tabela 1 apresenta a quantidade de flores comercializadas no mercado interno brasileiro, no período de 1997 a 1999.

Tabela 1. Quantidade de flores e plantas ornamentais comercializadas no período de 1997 a 1999. Adaptado de Aki (1999).

\begin{tabular}{lrrr}
\hline & 1997 & \multicolumn{1}{c}{1998} & 1999 \\
\hline Rosa (dz) & 27.700 .000 & 29.200 .000 & 32.400 .000 \\
Crisântemo & 11.000 .000 & 11.000 .000 & 13.000 .000 \\
Gérbera & 460.000 & 460.000 & 560.000 \\
\hline
\end{tabular}

Parte dos produtores que cultivam em ambientes protegidos possuem um bom conhecimento sobre a fisiologia e necessidades das culturas que exploram, procurando oferecer às plantas as melhores condições para seu desenvolvimento. Estes são representados principalmente pelos produtores de flores e plantas ornamentais, que investem na automatização e aperfeiçoamento do manejo do ambiente protegido.

No entanto, de acordo com Tivelli (1998), dos agricultores que deram início à produção em ambientes protegidos a partir de 1990, 70 a $80 \%$ abandonaram essa atividade por volta do segundo ano de cultivo, tendo como uma das principais razões o manejo inadequado do ambiente. Tal realidade aplica-se principalmente a pequenos agricultores, seja por falta de conhecimentos ou de capital, para investimento em sistemas sofisticados.

Muitos trabalhos têm sido realizados para estudar o cultivo em ambientes protegidos e as formas para melhor conduzí-los a baixo custo, mas ainda faltam informações sobre a dinâmica do seu microclima nas condições brasileiras, principalmente no que se refere à regulação da luminosidade, da temperatura e da umidade relativa do ar, elementos essenciais ao crescimento e desenvolvimento das plantas e àsua relação com pragas e doenças.

De acordo com Oliveira (1995), em levantamento realizado em todas as regiões brasileiras sobre o uso de ambientes protegidos, os maiores problemas enfrentados pelos agricultores, entre outros, eram: as altas temperaturas; a elevada umidade; a ocorrência freqüente de doenças e pragas e, principalmente, a falta de informações a respeito do manejo do microclima.

Em ambientes protegidos cobertos por plásticos, as alternativas mais simples e baratas utilizadas com o intuito de melhorar as condições do ambiente interno é a ventilação natural, uso de telas de sombreamento (forro e lateral) e a utilização de plásticos opacos (branco leitoso). 
Diante do exposto, este trabalho teve como objetivo geral avaliar, em ambientes protegidos, a utilização do polietileno de baixa densidade leitoso e de diferentes malhas de sombreamento, na produção de Gerbera jamesonii (Gérbera).

Os objetivos específicos deste trabalho foram os de analisar:

$\checkmark$ a influência de ambientes cobertos com filme de polietileno branco leitoso e diferentes malhas de sombreamento nas seguintes variáveis ambientais: irradiância solar global, irradiância fotossinteticamente ativa, temperatura, umidade relativa do ar e evapotranspiração.

$\checkmark$ a influência de ambientes cobertos com filme de polietileno branco leitoso e diferentes malhas de sombreamento e de seus respectivos microclimas no crescimento, no desenvolvimento e na qualidade da Gerbera jamesonii (Gérbera). 


\section{REVISÃo DE LITERATURA}

\subsection{A Cultura da gérbera}

As Gérberas são flores provenientes da Gerbera jamesonii, espécie ch família das Asteráceas, originária do sul da África (Gerstenberger \& Sigmund, 1980). São plantas perenes, herbáceas que possuem flor composta. O capítulo é formado por várias filas concêntricas de flores femininas liguladas, havendo, também, uma fila de flores hermafroditas e ao centro ficam as flores masculinas, assemelhando-se a grandes margaridas (Figura 1). Na natureza são encontradas na coloração que varia do amarelo ao laranja escuro, mas com o desenvolvimento de cultivares híbridos, disponibilizou-se no mercado grande variedade de cores, abrangendo: branco, nata, cor-de-rosa, vermelho, carmim e, até mesmo, violeta. As flores têm diâmetro que varia de 6,0 a $10,5 \mathrm{~cm}$ e haste de 30,5 a $46,0 \mathrm{~cm}$. As folhas variam, de acordo com a cultivar, em tamanho e em estrutura, podendo ter comprimento de 20,0 a 25,5 cm e arranjadas em roseta. O sistema radicular é, originalmente, pivotante, mas a medida que se desenvolve, converte-se em fasciculado e é composto por grossas raízes de onde partem numerosas radicelas (INFOAGRO, 2002). A propagação pode ser assexuada por divisão de touceiras ou cultura de tecido (Mascarini, 1998).

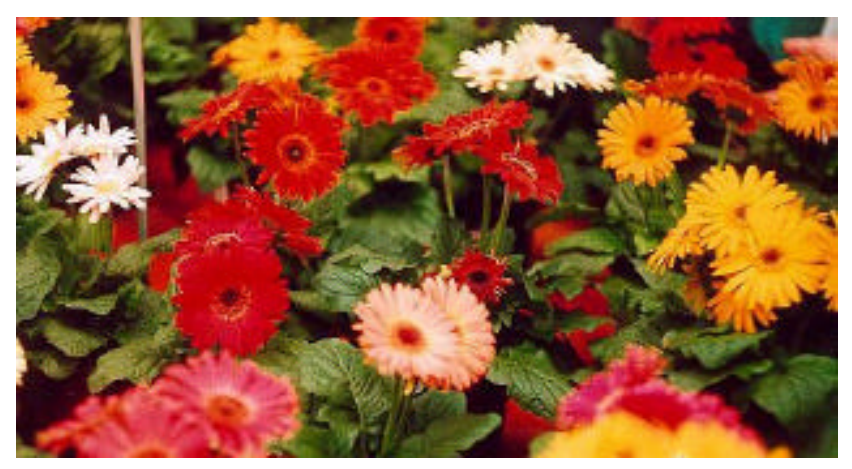

Figura 1 - Gerbera jamesonii - Gérbera. 
O ambiente exerce grande influência sobre as Gérberas, sendo que a temperatura do ar influência na emissão e no crescimento das folhas e na precocidade da floração. A temperatura do solo exerce efeito positivo sobre o diâmetro do capítulo e o comprimento da haste floral. As altas temperaturas, no momento do plantio e da irrigação, podem proporcionar desequilíbrio entre a parte aérea e as raízes da planta, sobretudo em solos pesados, onde o florescimento pode ser mais lento. As baixas temperaturas no inverno podem provocar anomalias e abortos florais, devido æ̀̀ deficiências fotossintéticas e à baixa absorção de nutrientes pelas raízes (INFOAGRO, 2002). A temperatura média para o bom desenvolvimento está entre $17{ }^{\circ} \mathrm{C}$ e $25^{\circ} \mathrm{C}$, no período diurno, e entre $13^{\circ} \mathrm{C}$ e $21^{\circ} \mathrm{C}$, no noturno (Leffring, 1975).

Lepori et al. (1979) relata que em regiões com alta insolação, como no mediterrâneo, durante o verão é recomendado o uso de sombreamento de $50 \%$ no interior dos ambientes protegidos, para que a produção não seja afetada pelas altas temperaturas.

Umidade relativa do ar entre $75 \%$ e $90 \%$ não representa problemas à cultura da Gérbera, porém, valores superiores podem favorecer a ocorrência de doenças, tais como Botrytis, e provocar manchas e deformações nas flores (INFOAGRO, 2002).

O substrato deve ter umidade uniforme, porém com boa aeração, de modo a se evitar a saturação (Leffring, 1975).

\subsection{Microclima em Ambientes Protegidos}

A utilização de ambientes protegidos por coberturas plásticas implica diversas modificações micrometeorológicas que alteram as relações planta-ambiente. A interceptação da radiação solar pela cobertura plástica reduz a incidência desta sobre as plantas, o que, conseqüentemente, irá alterar o balanço de radiação e de energia. Associado a isso, o processo convectivo originário do saldo de radiação positivo, é inibido pela cobertura plástica que retém o ar quente e o vapor, provocando alterações nos diversos elementos meteorológicos, em relação ao ambiente externo (Seemann, 1979).

\subsubsection{Radiação Solar}

A radiação solar é o principal elemento meteorológico, pois desencadeia todos os fenômenos meteorológicos, afetando todos os outros elementos como, por exemplo: temperatura, pressão, vento, umidade e chuva.

A radiação de onda curta influência o crescimento da planta em dois aspectos: a radiação fotossinteticamente ativa $(400$ a $700 \mathrm{~nm})$ é necessária para fotossíntese, processo 
básico para o desenvolvimento da planta (McCree, 1972), enquanto que o total de energia é o principal fator que afeta a transpiração (Gates, 1976).

A reflexão e a absorção promovidas pela cobertura plástica diminuem a incidência de radiação solar no interior do ambiente protegido (Seemann, 1979; Martin et al., 1982, Kurata, 1990, Sentelhas et al., 1997). Essa redução é variável em função do ângulo de incidência dos raios solares (Baytorun et al., 1994) e da transmitância do filme plástico, ou seja, do tipo (AlRiah et al., 1989; Sentelhas et al., 1997; Critten \& Bailey, 2002), idade (Reis \& Carrijo, 1999) e cor do filme (Sentelhas et al., 1999).

Conhecer as características de transmissividade da radiação de um material de cobertura é importante para avaliar os benefícios potenciais dos diferentes materiais, pois é conhecido que pequenas diferenças na transimitância de um material à radiação solar podem ter efeito significativo no crescimento e desenvolvimento da cultura (Kittas et al., 1999). Cockshull et al. (1992) constataram que o aumento de $1 \%$ da radiação fotossinteticamente ativa (PAR) proporcionou aumento de aproximadamente $1 \%$ nos rendimentos do tomateiro.

Giacomelli et al. (1988), investigando a relação entre a transmissividade da radiação solar global (285 a $2800 \mathrm{~nm}$ ) e da radiação fotossinteticamente ativa (400 a $700 \mathrm{~nm}$ ), em New Brunswick, NJ, entre abril e agosto de 1987, em uma estufa tipo arco geminada, coberta com filme duplo de polietileno, observaram que $67,4 \%$ da radiação solar global e $67,1 \%$ da radiação fotossinteticamente ativa registrada externamente atingiram o interior do ambiente protegido.

Com relação a sua opacidade, coloração ou transparência, os filmes plásticos apresentam resposta diferenciada quanto a absorção, a reflexão e a transmissão das radiações de onda curta e longa (Robledo \& Martin, 1981). Gonzales (1985) salienta, ainda, que é bastante comum na floricultura o interesse em diminuir a transmissão da radiação solar, podendo-se utilizar plásticos coloridos ou pintados, para aumentar a reflexão e/ou a absorção da radiação. De acordo com Critten \& Bailey (2002), a capacidade de absorção das coberturas também é proporcional àsua espessura.

Verlodt \& Waaijenberg (2000) afirmam que um filme transparente transmite os raios solares sem dispersá-los, tendo por resultado a transmissão elevada da luz direta. Nas regiões com irradiância solar elevada, isso pode induzir a queimadura das plantas, flores ou frutos. Esse efeito negativo pode ser minimizado com o uso de filmes aditivados, que difundem a luz sob a estufa inteira, de modo que mesmo as partes abaixo do dossel se iluminem. Este tipo de película é chamada de filme difuso ou opaco. Geralmente, esses tipos de filmes plásticos têm transmissão $5 \%$ menor do que um filme transparente. Essa redução é compensada por uma porcentagem maior de luz difusa, que tem um efeito positivo no desenvolvimento da cultura, especialmente naquelas que crescem eretas. 
Outra técnica adotada para redução da radiação solar no interior de ambientes protegidos é a pintura dos filmes de cobertura com tinta ou misturas brancas, que diminuem a carga de radiação transmitida para o interior do ambiente (Baille, 2001). Em recente estudo, Kittas et al. (1999) observaram que o branqueamento aplicado em vidro realçou a proporção de radiação fotossinteticamente ativa na radiação solar incidente total, reduzindo, assim, a fração dos comprimentos de onda infravermelha que penetra no ambiente.

A transmissividade depende também do comprimento de onda. Em geral, o polietileno de baixa densidade possui alta transmissividade na faixa do ultravioleta $(<300 \mathrm{~nm})$, sendo esta um pouco menor na faixa do infravermelho. Segundo Robledo \& Martin (1981), o PEBD transmite até $80 \%$ de radiação de onda longa. Sendo assim, o efeito estufa, ou seja, a retenção de ondas longas, seria pequena, determinando temperaturas mínimas noturnas no interior da estufa não muito diferentes do ambiente externo. Outros tipos de plástico, os chamados "plásticos térmicos", como EVA e o PEBD térmico, têm menor transmissividade à radiação de onda longa, evitando a queda acentuada da temperatura durante a noite (Sganzerla, 1995).

Kittas et al. (1999), analisando a distribuição da radiação solar no interior de ambientes protegidos, perceberam que materiais clássicos ou tecnificados de cobertura de estufa que obscurecem 0 ambiente protegido, mais conhecidos como malhas de sombreamento, geralmente são considerados como neutros em relação à distribuição da radiação solar, porém podem afetar significativamente alguns comprimentos de onda, principalmente na faixa do azul. Baille \& Tchamitchian (1993) citam que a intensidade de alguns comprimentos de onda de importância biológica para plantas, insetos ou patógenos pode ser aumentada ou diminuída, dando a possibilidade de controlar seu crescimento e desenvolvimento

Em experimento realizado em Piracicaba, SP, avaliando diferentes telas de sombreamento na atenuação da radiação solar, Sentelhas et al. (1997) verificaram que as telas branca, verde e preta utilizadas no experimento apresentaram atenuações médias da radiação solar global da ordem de $26,6 \%, 41,2 \%$ e $55,4 \%$, respectivamente, apesar de todas apresentarem malha de 50\%. Ricieri e Escobedo (1996) compararam em experimento a transmissão do polietileno e o polietileno associado a tela de sombreamento preta $50 \%$ em túneis. A transmissão foi, aproximadamente, $60 \%$ e $18 \%$, respectivamente.

\subsubsection{Temperatura do ar}

A temperatura do ar no interior de ambientes protegidos está intimamente ligada ao seu balanço de energia. Depende, portanto, dos processos de incidência da radiação solar, reflexão e re-irradiação através dos objetos no interior da estufa, convecção e condução através 
da cobertura e paredes, renovação do ar, evapotranspiração e troca de calor com o solo (Cermeño, 1993). A renovação de ar por meio de ventilação natural através da abertura de janelas e cortinas possibilita reduções significativas na temperatura no interior de estufas de polietileno (Furlan, 2001).

Segundo Seemann (1979), a temperatura do ar no interior do ambiente protegido é variável, principalmente, com o seu tamanho e volume, com o tipo de cobertura, com a abertura ou não de janelas e cortinas, com o ângulo de incidência dos raios solares e com a cobertura do solo. Entretanto, as temperaturas mínimas e médias são pouco afetadas, ocorrendo o maior efeito sobre as temperaturas máximas.

A distribuição horizontal da temperatura do ar no interior dos ambientes protegidos não é homogênea. Devido à baixa ventilação há formação de ilhas de calor no centro do ambiente, problema que nem sempre consegue ser solucionado, mesmo com a abertura das cortinas laterais e das janelas zenitais (Furlan, 2001).

Mills et al. (1990), avaliando o microclima no interior de túneis altos cobertos com plástico, na África do Sul, atribuíram à radiação a principal causa das altas temperaturas observadas no ambiente protegido durante o dia. No entanto, as temperaturas mínimas, quando comparadas com as do ambiente externo, não apresentaram muita discrepância. Conclusão semelhante também foi obtida por Semedo (1988).

Furlan (2001), estudando ambientes protegidos com diferentes manejos de ventilação natural e nebulização, em Piracicaba, SP, avaliou também o saldo de radiação. Os dados obtidos no mês de novembro (primavera), permitiram concluir que, entre o nascer e o pôr do sol, o saldo de radiação é maior no ambiente externo. No entanto, durante a noite quando o saldo de radiação é negativo devido à ausência de radiação solar incidente, o valor verificado sob a cobertura plástica é menos negativo, ou seja, maior no ambiente protegido do que no ambiente externo, o que, no entanto, não chegou a provocar diferenças na temperatura noturna entre os dois ambientes.

De acordo com Alpi \& Tognoni (1991), as variações de temperatura verificadas no interior de estufas, notadamente no sentido vertical, são consequência direta dos fenômenos de transmissão de calor por irradiação, condução e, principalmente, convecção. Sendo assim, ocorre um gradiente de temperatura, no interior da estufa, variando de um mínimo, próximo ao solo, até um máximo, contíguo ao teto, o que foi observado por Buriol et al. (1997) e por Furlan (2001) em condições brasileiras.

Faria Jr. et al. (1993), avaliando cultivares de alface em ambiente protegido, bem como o microclima formado por modelos distintos de estufas plásticas (Arco e Capela), em Ilha Solteira, SP, verificaram que os valores de temperatura máxima foram mais elevados nas 
estufas que na testemunha sem proteção plástica (entre 3 e $5 \stackrel{\circ}{\circ}$ ). Em relação æ̀s temperaturas mínimas, as diferenças foram muito pequenas $(0,3 \stackrel{\circ}{\circ})$.

Em experimento realizado em Rio Largo, AL, comparando dois ambientes protegidos, um coberto com sombrite preto $(50 \%)$ e outro por polietileno de baixa densidade, Nascimento Filho et al. (1997) œnstataram que em dia de céu limpo os valores de temperatura máxima do ar no interior do ambiente protegido com a tela preta foram constantemente superiores aos encontrados no ambiente coberto pelo polietileno de baixa densidade. $\mathrm{Na}$ condição de dia nublado, com chuva, a temperatura do ar no exterior se manteve superior aos demais ambientes, sendo os valores no interior da estufa com sombrite os mais baixos, muito semelhantes ao da estufa com polietileno de baixa densidade.

Mais recentemente, tem sido colocada à disposição dos produtores uma malha termorefletora que, instalada na altura do pé direito de estruturas com 3 a 4 metros de altura, proporciona uma boa redução da temperatura sem influir demasiadamente na luminosidade como as telas de sombreamento convencionais (pretas). Apesar desta vantagem, a malha termo-refletora ainda apresenta um alto custo, sendo viável apenas para alguns poucos cultivos de elevado valor agregado (Goto e Tivelli, 1998). Contestando sua eficácia, Abak et al. (1994), em estudo avaliando materiais de cobertura em ambientes protegidos, verificaram que em estufas plásticas com malha termo-refletora a temperatura do ar e do solo foi superior às observadas nas estufas sem malha.

\subsubsection{Umidade Relativa do ar}

De acordo com Seemann (1979), Tanaka e Genta (1982) e Farias et al., (1993) os valores da umidade relativa do ar são inversamente proporcionais à temperatura do ar e muito variáveis no interior do ambiente protegido. Desta forma, com o aumento da temperatura, durante o período diurno, a umidade relativa diminui no interior da estufa, tornando-se igual ou inferior à umidade observada externamente, sendo que, durante a noite, a umidade relativa aumenta bastante, freqüentemente próxima a 100\%, devido à queda acentuada na temperatura verificada neste período, e à retenção de vapor d'água pela cobertura plástica (Sentelhas e Santos, 1995; Buriol, 2000; Furlan, 2001).

A umidade em ambientes protegidos existe sob duas formas: vapor d'água e água liquida. Além de estar presente no solo, a água Ivre também pode ocorrer na superfície das plantas, muitas vezes, pela condensação do vapor d'água, resultante do resfriamento, até atingir o ponto de orvalho. A formação de orvalho na superfície das folhas e na face interna do filme plástico é bastante comum em estufas e propicia condições favoráveis à infecção por patógenos. Além disso, a umidade absoluta do ar, originada da evapotranspiração, costuma ser 
maior do que no ambiente externo. Esses dois tipos de umidade constituem o principal fator ambiental para doenças foliares (Araujo \& Castelani, 1991). Uma das principais desvantagens da cobertura plástica em estufas é a condensação da água na face interna da cobertura (Baytorun, 1994), que precipita, aumentando o molhamento foliar.

O aparecimento e o desenvolvimento de doenças são resultante da interação entre uma planta suscetível, um agente patogênico e fatores ambientais favoráveis. $O$ ambiente, portanto, é um componente relevante nesta interação, podendo, inclusive, impedir a ocorrência da doença mesmo quando há fonte de inóculo. Doenças altamente destrutivas podem passar desapercebidas sob certas condições ambientais (Bedendo, 1995).

Um grande diferencial na variação da umidade relativa em ambientes protegidos com cobertura plástica é a abertura ou não de cortinas e janelas. A utilização de cortinas abertas possibilita que os ventos, que circulam no interior da cobertura plástica, transportem com mais facilidade o calor sensível e o vapor d'água para o exterior, controlando a umidade e a temperatura no interior do ambiente protegido (Reis, 1997).

De acordo com Furlan (2001), com a abertura das cortinas laterais e janela zenital, a umidade relativa do ar diminui acentuadamente quando comparada com o ambiente fechado, devido à redução da temperatura do ar. O mesmo autor verificou que o sistema de nebulização, apesar de promover a redução da temperatura do ar, eleva a umidade.

Oliveira (1995), listando as principais desvantagens do emprego de casas de vegetação no Brasil, citou que nos meses mais quentes (dezembro, janeiro e fevereiro), o manejo da umidade relativa do ar e do sistema de resfriamento do ambiente, por não serem eficientes, permitem a ocorrência de condições microclimáticas de alta umidade, que provocam desordens fisiológicas como deformações e necrose de tecidos foliares. O autor enfatiza, ainda, que o controle da umidade relativa do ar, ventilação e o sistema de irrigação precisam ser melhor estudados e elaborados de acordo com o clima de cada região.

\subsubsection{Vento}

Segundo Righi (2000), o vento aumenta a renovação de ar em torno da folha, aumentando a condutância aerodinâmica, resultando em valores de transpiração das plantas mais elevados. No interior da estufa, quando ventilada, ocorre a remoção do ar úmido, entrando ar mais seco e menos quente vindo do exterior do ambiente, o que também contribui para o aumento da evapotranspiração.

A velocidade do vento no interior da estufa é estimada em $5 \%$ do verificado externamente (Farias et al., 1994). Isto pode se constituir em uma vantagem, à medida que melhora a eficiência de defensivos, pois diminui perdas, diminui o risco de danos mecânicos æ̀̀ 
plantas e de disseminação de esporos de fungos ou outros patógenos. No entanto, os problemas relacionados com o vento no interior de ambientes protegidos estão quase sempre ligados à sua baixa velocidade. $\mathrm{O}$ que se tem buscado até então, são meios de melhorar o aproveitamento do vento, visando-se proporcionar uma renovação do ar mais eficiente nesses ambientes, a fim de se diminuir a temperatura e a umidade excessivas.

A variação da umidade do ar no interior de estufas depende principalmente da temperatura do ar e da ventilação. Por sua vez, a temperatura do ar varia principalmente em função da densidade de fluxo de radiação solar incidente e da própria ventilação, a qual depende da área, tipo, localização e manejo das aberturas e da velocidade de troca do ar do interior com o exterior (Seemann, 1979; Buriol et al., 2000; Critten \& Bailey, 2002).

O resfriamento de ambientes protegidos é um assunto que tem ganhado importância nos países de clima quente, onde altas temperaturas do ar e déficit de saturação de vapor elevados são freqüentemente observados em ambientes protegidos durante o verão. Vários métodos de resfriamento do ambiente podem ser utilizados para manter condições mais favoráveis ao desenvolvimento das plantas. A ventilação é um dos mais utilizados (Boulard et al., 1997, Kittas et al., 1999).

Há dois tipos de ventilação, a natural e a forçada. A natural depende basicamente do formato das instalações e das características climáticas regionais. A ventilação forçada ocorre através de exaustores ou ventiladores, devidamente dimensionados e posicionados nas estufas (Hardoim, 1995).

De acordo com Martins \& Gonzales (1995a), a ventilação natural é um fator extremamente importante, pois controla a umidade relativa, evita o calor excessivo durante 0 dia e assegura a taxa mínima de $\mathrm{CO}_{2}$. A ventilação natural é um dos principais mecanismos de controle das condições meteorológicas em ambientes protegidos, responsável pelos balanços de energia e de massa (água e $\mathrm{CO}_{2}$ ), mas ainda é uma técnica pouco estudada devido à complexidade da sua análise (Boulard et al., 1996).

$\mathrm{Na}$ ausência de vento, a ventilação natural no interior das instalações pode ocorrer pelo aquecimento diferencial do ar. $\mathrm{O}$ ar é um fluido cujas características resultam em expansão volumétrica à medida que a temperatura aumenta. Isto significa que 0 ar mais quente é menos denso que o ar mais frio, logo, o ar mais denso e frio tende a descer, e o ar mais quente e menos denso tende a subir. Geralmente, o ar mais próximo ao solo se aquece mais rapidamente, gerando um fluxo ascendente do ar mais aquecido, podendo ser eliminado por aberturas na cobertura do ambiente, permitindo a entrada de ar mais frio pelas laterais. Esse fluxo ascendente, resultante do aquecimento diferencial do ar, que ocasiona a ventilação é conhecido como efeito "termo-sifão". 
Burn \& Lagier (1985), desenvolvendo um novo modelo de estufa que se adaptasse as condições climáticas do mediterrâneo, concluíram que a estufa que se utilizava do efeito "termosifão" foi a que permitiu melhor rendimento da cultura de tomate e melhor índice de controle de temperatura.

Feuilloley et al. (1990) e Rault (1990) compararam diferentes modelos de estufas para determinar qual a mais eficiente em regiões de clima quente, e concluíram que as estufas com abertura no teto e nas laterais são as mais eficientes, pois geram uma excelente circulação de ar. Ainda, de acordo com Rault (1990), é necessário o desenvolvimento de estufas que possuam um efeito "termo-sifão" eficiente, pois em regiões de clima quente a temperatura do ar no interior de estufas, durante o dia, pode vir a ser prejudicial para o desenvolvimento das plantas. Outra grande vantagem de se utilizar estufas com sistemas de ventilação natural é que o custo de instalação e de manutenção deste tipo de sistema é bem inferior se comparado aos sistemas mecânicos, pouco acessíveis aos pequenos produtores.

A ventilação dos ambientes protegidos deve ser realizada nas horas em que a temperatura se eleva acima do limite ótimo de que necessitam as culturas. Portanto, as instalações devem possuir suficiente superfície de ventilação e seu mecanismo de abertura e fechamento deve ser rápido e fácil (Cermeño, 1994).

\subsubsection{Evapotranspiração}

A condição meteorológica é um dos principais fatores na determinação da quantidade de água evapotranspirada pelas culturas. Além dos fatores climáticos, a evapotranspiração também é influenciada pela própria cultura (área foliar) e pela disponibilidade de água no solo (Pereira et al., 2002). Alterações no ambiente e o sistema de cultivo adotado também podem influenciar a taxa de crescimento e a evapotranspiração das culturas (Doorenbos \& Pruitt, 1997).

A cobertura plástica utilizada em estufas é responsável por alteração significativa no balanço de radiação que ocorre em seu interior, em relação ao ambiente externo, devido à atenuação causada pela cobertura na radiação solar incidente, o que acaba resultando em redução no saldo de radiação interno (Furlan, 2001) e, conseqüentemente, na evapotranspiração. Assim, no interior de estufas a evapotranspiração é, geralmente, menor do que aquela que ocorre no ambiente externo, devido não somente à redução no saldo de radiação, mas também à menor ventilação e à maior umidade do ar (Pereira et al., 2002). Segundo Martins \& Gonzáles (1995b), os principais fatores da demanda evapotranspirativa são a incidência de radiação solar e a ação dos ventos, entretanto, a temperatura elevada e a baixa 
umidade relativa, em alguns momentos, contribuem para o aumento da evapotranspiração no ambiente protegido. Farias et al. (1994) relataram que a evapotranspiração dentro do ambiente protegido variou de 45 a $77 \%$ da verificada externamente.

Medeiros et al. (1997) comparando a evaporação medida em tanque classe A e em mini-tanques (diâmetro de 0,6 m de diâmetro e 0,25 m de altura), instalados no interior de estufa plástica, no período primavera-verão, em Piracicaba, SP, observaram que a evaporação interna foi, em média, $47 \%$ da evaporação externa, independente do tipo de tanque utilizado. A relação evaporação interna e externa variou de 20 a 70\%, sendo essa larga amplitude atribuída àação dos ventos, que atuam principalmente no ambiente externo.

Faccioli (1998) concluiu que o método de Penman-Monteith pode ser utilizado como padrão na estimativa do potencial de evapotranspiração no interior de ambientes protegidos por cobertura plástica. Segundo o autor, a evapotranspiração estimada pelo método de PenmanMonteith não necessita de ajustes quando se utilizam os dados obtidos no interior do ambiente protegido. Observações semelhantes foram feitas por Folegatti et al. (1997): "Os elementos meteorológicos determinados no interior da estufa são os que permitem uma melhor estimativa da evapotranspiração e a radiação solar global é o elemento meteorológico mais importante na estimativa da evapotranspiração da cultura em estufa."

Estudando modelos para estimativa da evapotranspiração no interior de ambientes protegidos, Scatolini (1996) chegou às seguintes conclusões: o ambiente protegido altera os elementos meteorológicos de maneira não uniforme, dificultando a estimativa da evapotranspiração a partir de elementos externos; as principais variáveis a serem consideradas na estimativa da evapotranspiração no interior do ambiente protegido são a radiação solar global e o índice de área foliar, sendo que os demais elementos meteorológicos, embora influenciem a evapotranspiração, não proporcionam grandes alterações na sua estimativa (inferiores a $1 \%$ ).

Viana (2000), avaliando a evapotranspiração da cultura de alface em ambiente protegido, concluiu que o método da Razão de Bowen não apresentou um bom desempenho na estimativa diária da evapotranspiração, em comparação com os valores medidos através de um lisímetro de pesagem. A redução da velocidade do vento e a contenção dos movimentos convectivos pela cobertura plástica diminuem a renovação das camadas de ar. Isso ocasiona baixos valores de gradiente de pressão parcial de vapor, o que dificulta a estimativa da evapotranspiração por este método. 


\section{MATERIAL E MÉTODOS}

\subsection{Período e localização}

O experimento foi realizado entre o outono e o inverno de 2002, junto à área experimental do Departamento de Ciências Exatas, da E.S.A. "Luiz de Queiroz", Universidade de São Paulo (ESALQ-USP), no município de Piracicaba, Estado de São Paulo, localizada nas seguintes coordenadas geográficas: Latitude de $22^{\circ} 42^{\prime} 40^{\prime \prime} \mathrm{S}$, Longitude de $47^{\circ}$ 37' 30" W e altitude de 546 metros. O clima da região segundo a classificação de Köppen, é Cwa, tropical úmido com seca no inverno.

\subsection{Ambiente Protegido}

Foi instalado um ambiente protegido, sub-dividido em três partes iguais, cada uma tendo $15 \mathrm{~m}$ de comprimento, totalizando $45 \mathrm{~m}$. As demais dimensões foram de $6,4 \mathrm{~m}$ de largura, $3 \mathrm{~m}$ de pé direito e 4,2 $\mathrm{m}$ de altura total (pé direito + arco), correspondendo a uma área total de $288 \mathrm{~m}^{2}$ e volume aproximado de $1209 \mathrm{~m}^{3}$ (Figura 2).

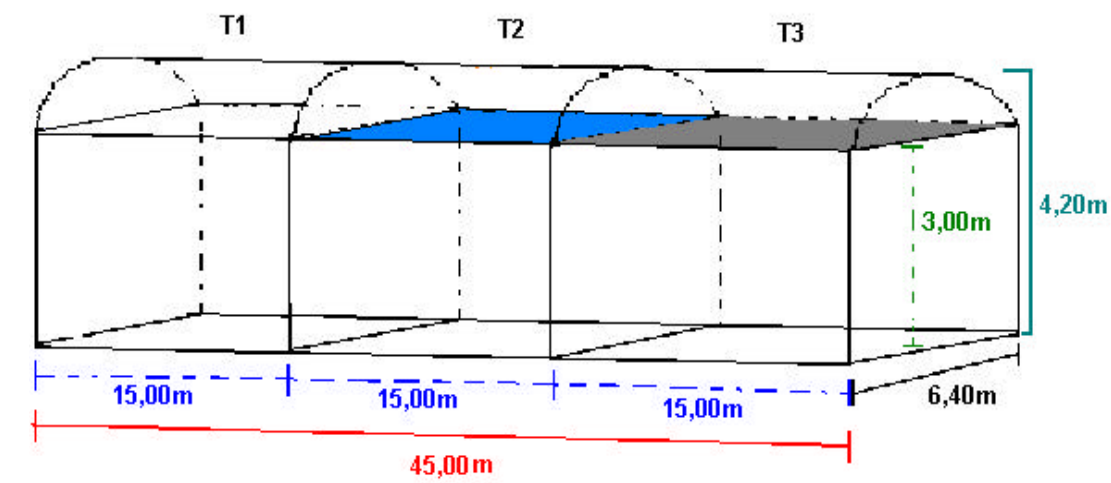

Figura 2 - Representação esquemática dos ambientes protegidos, suas dimensões e os tratamentos adotados: T1 - plástico leitoso; T2 - plástico leitoso + malha termorefletora e T3 - plástico leitoso + malha preta. 
O material utilizado para cobrir e dividir os três ambientes foi o filme de polietileno de baixa densidade (PEBD) leitoso, de $0,15 \mathrm{~mm}$ de espessura. Nas laterais da estrutura foi colocada malha de sombreamento $50 \%$ (Figura 3).

Um dos ambientes era coberto apenas pelo plástico leitoso (T1), enquanto os outros dois possuíam, ainda, malhas de sombreamento, que foram instaladas internamente, à altura do pé direito, sendo um com malha termo-refletora (Alumitela) (T2) e outro com malha preta (T3), como apresentado nas Figuras 2 e 4, ambas com 50\% de sombreamento e fabricadas pela Solpack Ltda, constituindo-se, assim, três tratamentos.

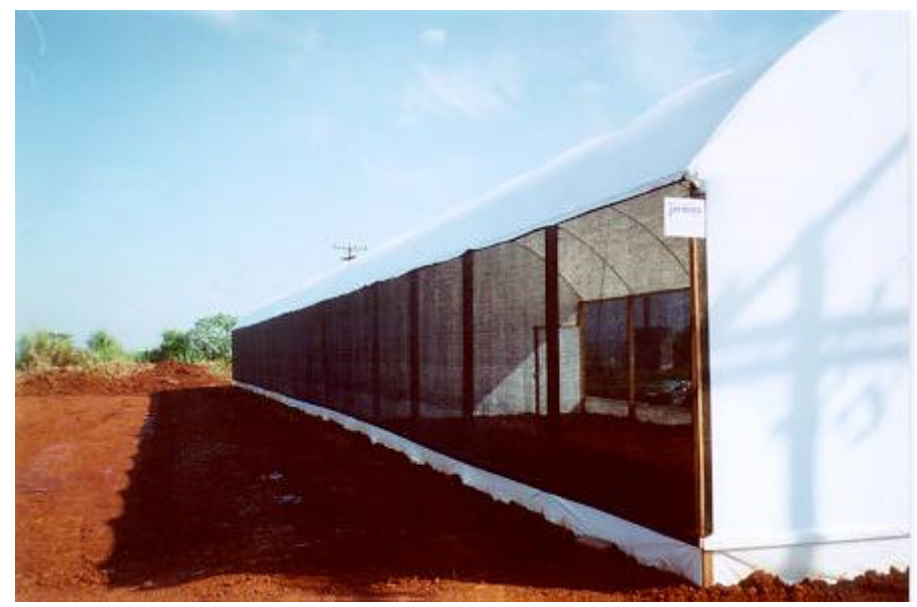

Figura 3 - Vista lateral do ambiente protegido, com malha de sombreamento preta (50\%) nas paredes.

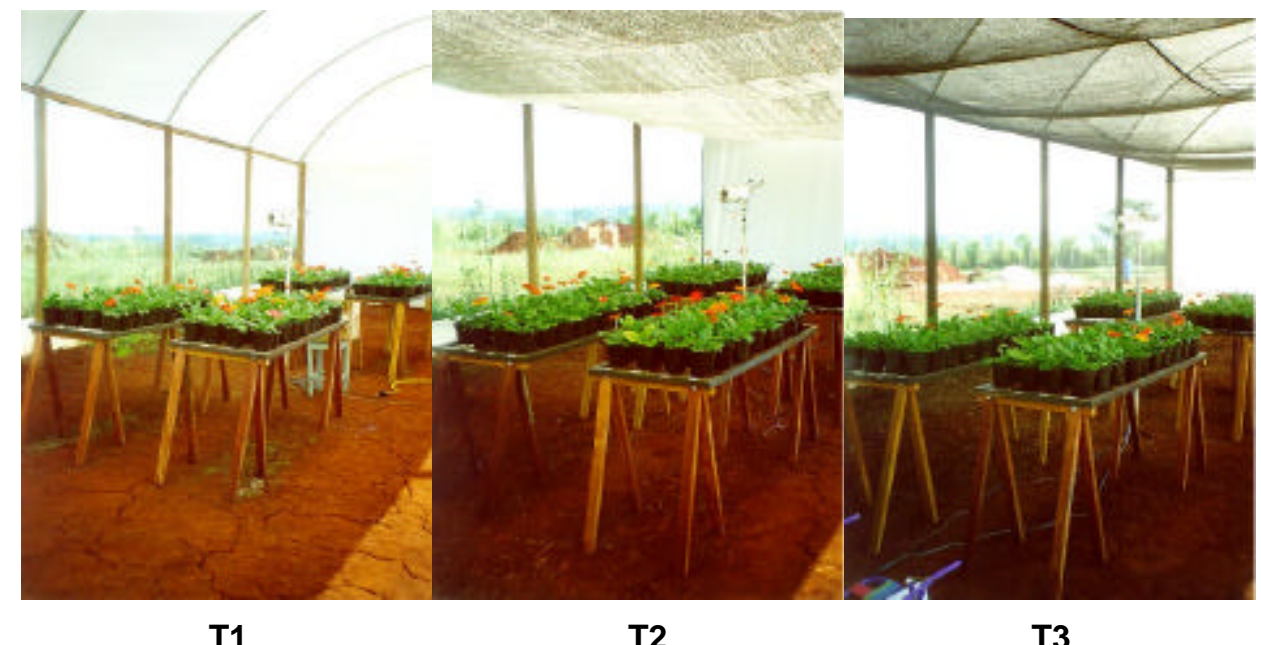

Figura 4 - Vista interna dos ambientes protegidos cultivados com Gérbera, sendo T1 - plástico leitoso, T2 - plástico leitoso + malha termo-refletora e T3 - plástico leitoso + malha preta. 


\subsection{Instalação e Condução da Cultura da Gérbera}

Para a instalação da cultura da Gérbera foram utilizadas mudas de padrão comercial de Gerbera jamesonii (Gérbera Jaguar Fómula Mix), adquiridas diretamente de produtor especializado (Syngenta Seeds LTDA).

As mudas foram transplantadas para vasos número $15(15 \mathrm{~cm}$ de diâmetro e $11,5 \mathrm{~cm}$ de altura), preenchidos com substrato comercial (Multisoil) tendo em sua composição: casca de pinus, turfa, carvão, fosmag, FTE e calcário, fabricado pela Terra do Paraíso.

No interior de cada tratamento foram colocados 160 vasos, divididos em 4 blocos de 40 vasos, totalizando 480 vasos nos três ambientes.

A Figura 5 apresenta, esquematicamente, uma visão geral, da organização interna de um dos tratamentos do ambiente protegido, com as bancadas e vasos.

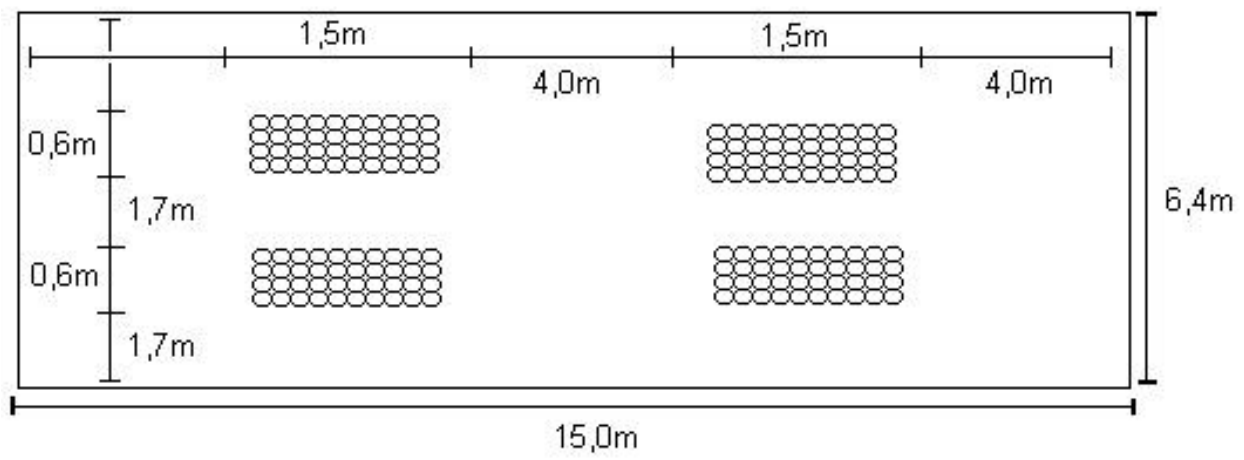

Figura 5 - Representação esquemática da disposição das bancadas e dos vasos no interior do ambiente protegido.

\subsection{Sistema e Manejo da Fertirrigação}

A irrigação e a fertirrigação foram feitas manualmente, obedecendo a demanda da cultura. A fertirrigação foi alternada, ou seja, um dia utilizou-se a solução da caixa $A$ e outro da caixa B, sendo feita de acordo com a recomendação apresentada na Tabela 2. 
Tabela 2. Recomendação de fertirrigação para Gerbera jamesonii, caixa A e caixa B.

\begin{tabular}{|c|c|}
\hline Caixa A: & Caixa B: \\
\hline Nitrato de cálcio................800g/1000l & Nitrato de potássio............700g/1000l \\
\hline Nitrato de amônia ...............400g/1000l & Sulfato de magnésio........600g/1000l \\
\hline Tenso Ferro .....................10g/1000l & MAP \\
\hline 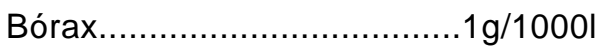 & Tenso cocktail...... \\
\hline
\end{tabular}

Fonte: Steinberg (2002)

\subsection{Tratos Culturais}

Para o bom desenvolvimento da cultura, foi necessária a adoção de tratos culturais adequados: limpeza de folhas danificadas por injúrias, tratos fitossanitários e retirada de eventuais plantas daninhas.

\subsection{Variáveis Meteorológicas}

A fim de se avaliar e caracterizar os ambientes dos três tratamentos, foram realizados registros contínuos de dados meteorológicos em cada um deles, utilizando-se sistemas automáticos de coleta de dados. Simultaneamente, as mesmas variáveis foram obtidas em uma estação meteorológica automática instalada externamente a menos de $100 \mathrm{~m}$ do local do experimento.

\subsubsection{Temperatura e Umidade Relativa do ar}

Os dados relativos à temperatura e umidade relativa do ar foram obtidos com psicrômetros de termopar aspirado, de baixo custo e fácil utilização em sistemas automáticos de aquisição de dados, como descrito em Marin et al. (2001). A aspiração é feita por ventiladores utilizados em micro-computadores ("cooler") e as temperaturas são determinadas com junções de termopar de cobre-constantan, sendo que uma medindo a temperatura do ar e outra a temperatura do bulbo úmido. Os psicrômetros estavam conectados a sistemas de aquisição de dados, modelos CR10 e CR23x da Campbell Sci. Os dados foram obtidos ao longo da condução do ciclo da cultura, nos três ambientes. Os sensores foram instalados no centro de cada ambiente estudado, ou seja, metade do comprimento e metade da largura e a

\footnotetext{
${ }^{1}$ STEINBERG, E., (Syngenta Seeds LTDA) Comunicação pessoal, 2002.
} 
altura de 1,5 m (Figuras 6 e 7), conforme recomendação de Furlan (2001), sendo um psicrômetro por ambiente.

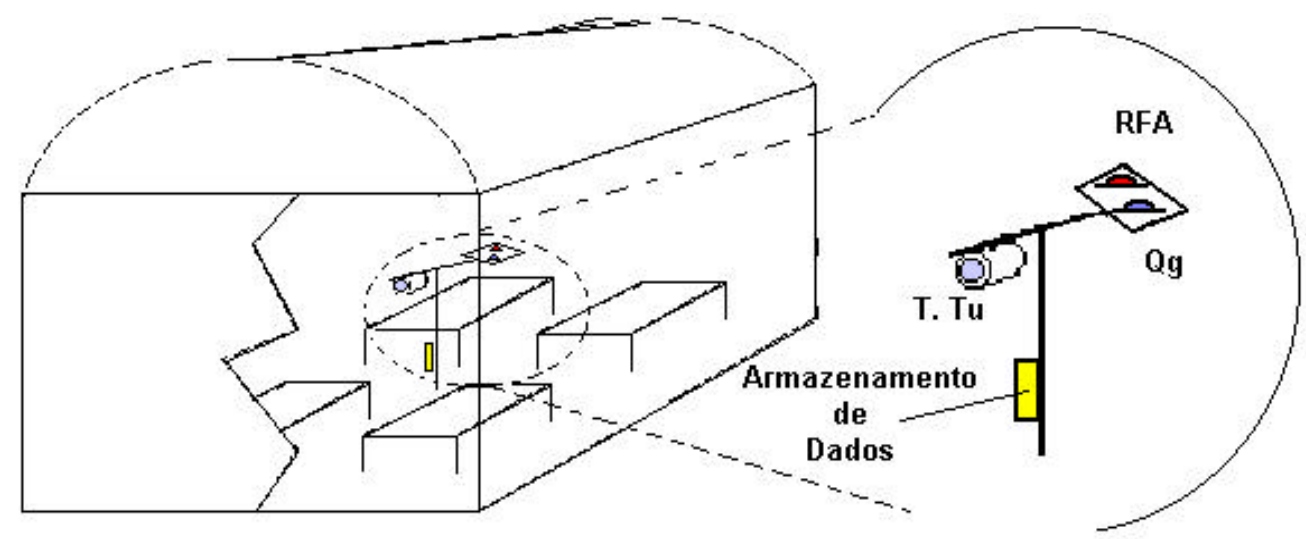

Figura 6 - Representação esquemática do ambiente protegido com as bancadas de vasos e os instrumentos meteorológicos (detalhe): Radiação global $(\mathrm{Qg})$, radiação fotossinteticamente ativa (RFA), Temperatura de bulbo seco (T) e temperatura de bulbo úmido (Tu) (ventilado) e Sistema automático de aquisição de dados.

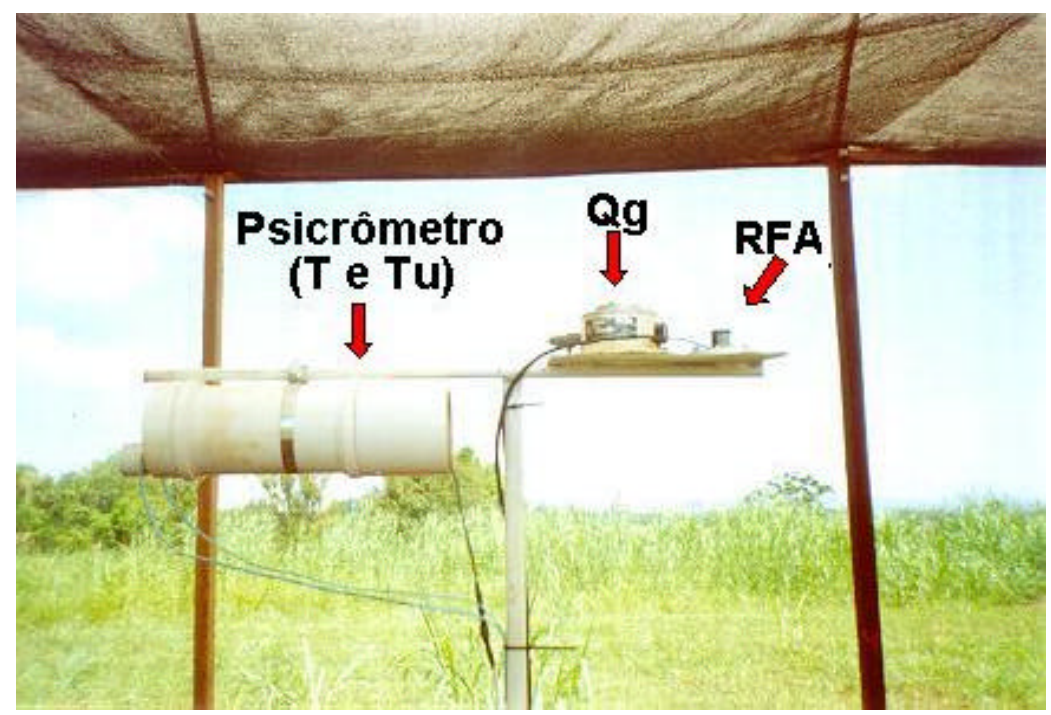

Figura 7 - Instrumentos meteorológicos instalados em cada tratamento: radiação solar global $(\mathrm{Qg})$, radiação fotossinteticamente ativa (RFA), temperatura de bulbo seco $(\mathrm{T})$ e temperatura de bulbo úmido (Tu) (psicrômetro ventilado). 
Os dados externos de temperatura e umidade relativa foram obtidos por um sensor HMP45C da Vaisala Inc., instalado na estação meteorológica automática, pertencente ao Departamento de Ciências Exatas/ESALQ/USP, próxima ao local do experimento.

Ao longo do período do experimento (16/04/2002 a 26/05/2002), os dados foram lidos a cada segundo e armazenados em sistema automático de aquisição de dados, a intervalos de 15 minutos. As variáveis respostas do experimento (temperatura e umidade relativa do ar) foram utilizadas para a comparação dos diferentes tratamentos.

\subsubsection{Radiação Solar}

Em cada ambiente protegido foram conectados ao sistema de aquisição de dados (CR10 e CR23X), sensores para medida da irradiância solar global e da irradiância fotossinteticamente ativa. Todos os sensores de radiação foram instalados no centro do ambiente, juntamente com os psicrômetros (Figuras 6 e 7).

Para a medida da irradiância solar global foram utilizados três sensores diferentes: CM3 (Kipp \& Zonen), PSP (Eppley) e Li200x (Li-cor), que foram previamente calibrados, tendose como referência o sensor da Eppley (Figura 8).

Os dados referentes à radiação fotossinteticamente ativa foram obtidos com três sensores, LI190SB do tipo Quantum, faixa espectral de 400 a $700 \mathrm{~nm}$, da marca Li-cor, sendo um para cada ambiente protegido. A calibração dos sensores foi realizada tendo como referência um sensor do tipo PSP (Eppley) adaptado com um filtro seletivo para a faixa espectral de $697 \mathrm{~nm}$ (Figura 9).
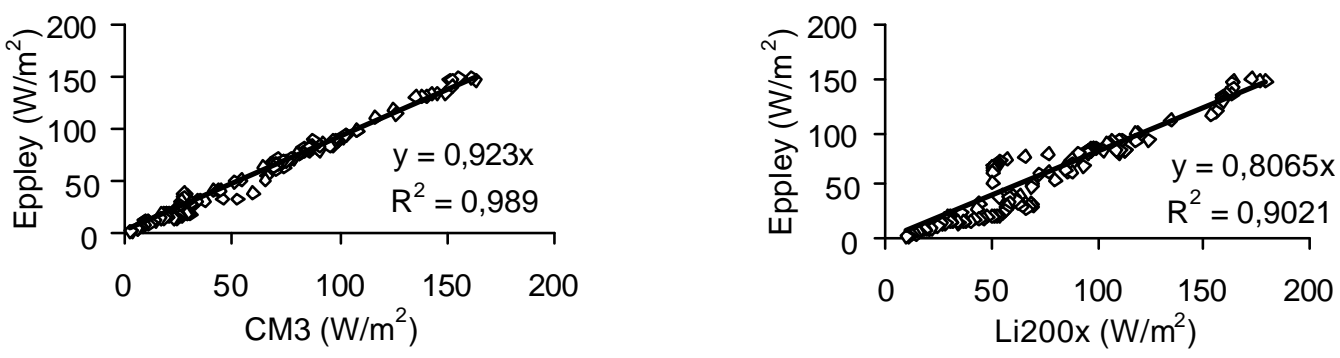

Figura 8 - Calibração dos sensores CM3 e Li200, para medida da radiação solar global, tendose como referência o sensor PSP-Eppley. 

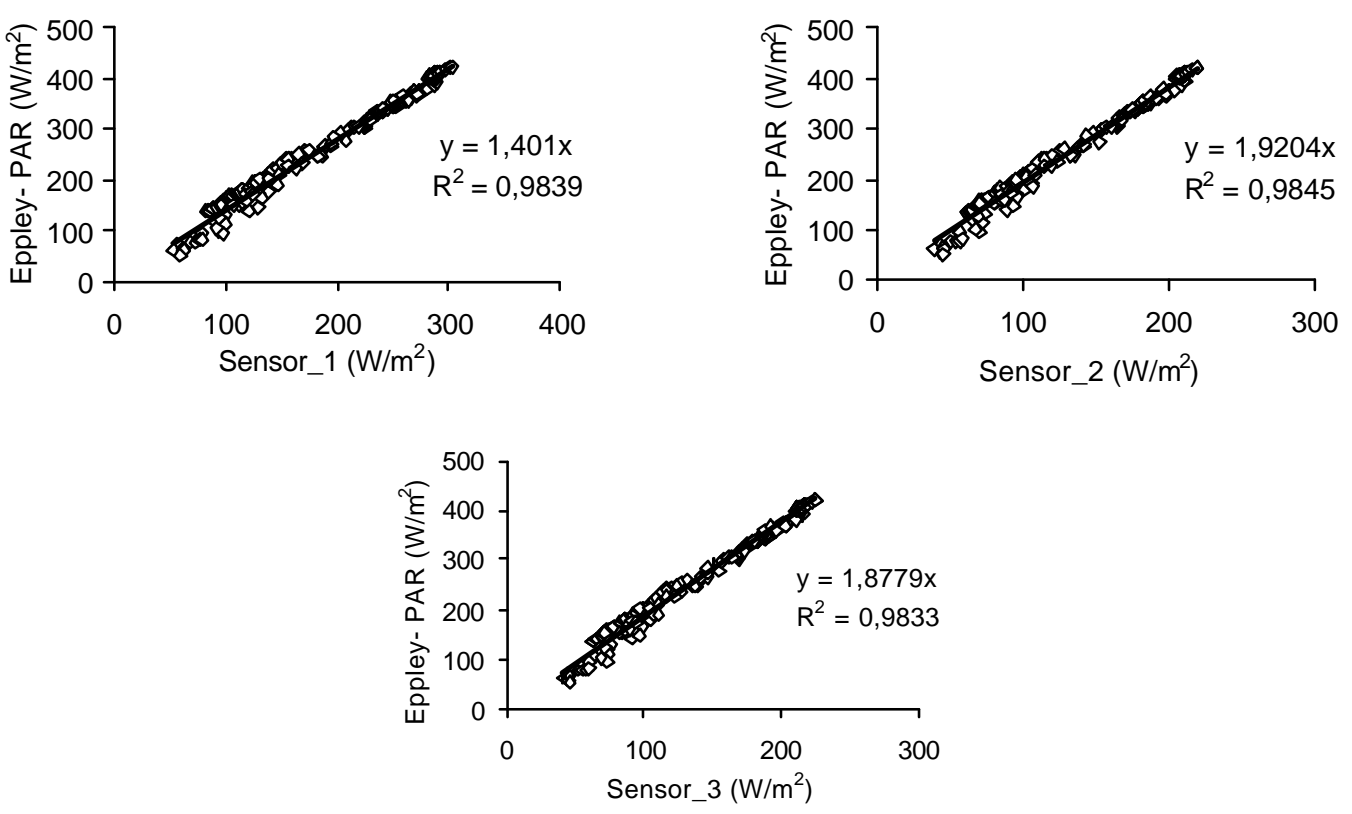

Figura 9 - Calibração dos sensores LI190SB do tipo Quantum, para a medida da radiação fotossinteticamente ativa, tendo-se como referência o sensor PSP-Eppley com filtro para a faixa espectral de $697 \mathrm{~nm}$.

\subsection{Evapotranspiração da gérbera}

A evapotranspiração de cultura foi determinada pelo método gravimétrico. Uma amostra (um vaso) por repetição de cada tratamento, sendo 3 tratamentos com 16 repetições cada, totalizando 48 vasos, foi pesada em balança digital da marca Marte com precisão $0,1 \mathrm{~g}$ (Figura 10).

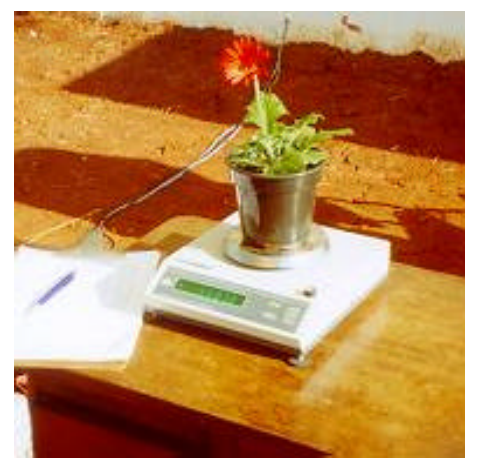

Figura 10 - Balança de precisão utilizada para a pesagem dos vasos na determinação da evapotranspiração da Gérbera. 
A evapotranspiração da cultura nos diferentes tratamentos avaliados foi obtida pela diferença de peso nos intervalos de pesagem. A evapotranspiração em $\mathrm{mm}$ foi obtida levandose em conta a área do vaso. Foram realizados 3 dias de medidas (27/04/2002, 10/05/2002 e 18/05/2002), com intervalos de $1 \mathrm{~h}$, iniciando-se æ̀s $9 \mathrm{~h}$ e finalizando-se æ̀̀ $17 \mathrm{~h}$.

\subsection{Variáveis da cultura}

Foram avaliados 4 amostras por repetição de cada sub-divisão (tratamento), sendo 3 tratamentos com 16 repetições cada, totalizando 64 vasos avaliados no experimento. As medições foram realizadas semanalmente a partir do transplantio das mudas até o final do ciclo da cultura.

Nessa análise avaliou-se as seguintes variáveis:

$\checkmark \quad$ Número de folhas: foram contabilizados o número de folhas totais por vaso.

$\checkmark$ Diâmetro e altura da planta: as medidas foram feitas manualmente com auxilio de régua graduada em milímetros, a partir dos pontos extremos encontrados na planta (Figuras 11a e 11b).

$\checkmark$ Número de botões florais: foram contabilizados, tanto os botões quanto as inflorescências, em cada vaso.

$\checkmark$ Altura da haste: foram obtidas com régua graduada em milímetros, a partir da base até a inserção do capítulo (Figura 11c)

$\checkmark$ Diâmetro do capítulo: as medidas foram realizadas por meio de régua graduada em milímetros (Figura 11d).

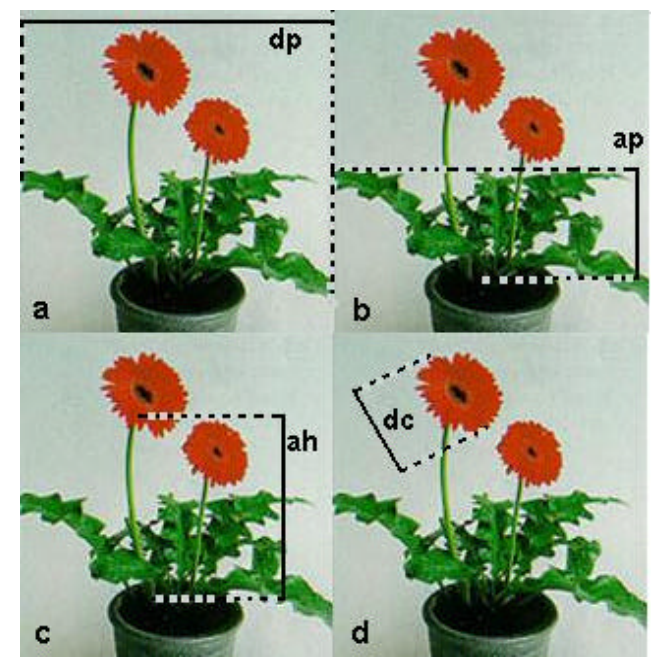

Figura 11 - Variáveis da cultura: (a) diâmetro da planta, dp, (b) altura da planta, ap, (c) altura da haste, ah e (d) diâmetro do capítulo, dc. 


\subsection{Análise dos dados}

Os dados foram analisados a fim de se determinar os efeitos de cada tratamento sobre: o microclima, por meio das variáveis meteorológicas e da evapotranspiração da cultura; e o crescimento das plantas, por meio das variáveis da cultura da Gérbera.

A partir dos dados de radiação solar global $(\mathrm{Qg})$ e fotossinteticamente ativa (RFA) foram obtidas e analisadas as transmitâncias de cada material de cobertura (plástico leitoso, plástico leitoso + malha termo-refletora e plástico leitoso + malha preta), a variação diária ao longo do experimento e horária para os tratamentos adotados e ambiente externo, no dia de insolação (n) igual à 10 h.d $d^{-1}$ (17/04, céu limpo) e no dia de insolação de 4,2 h.d ${ }^{-1}$ (30/04, céu nublado) e a partição percentual da radiação solar global em fotossinteticamente ativa e ultravioleta mais infravermelho próximo (UV+IVP), por regressões lineares, para os ambientes protegidos estudados e ambiente externo.

As variações da temperatura do ar no interior dos ambientes protegidos e na estação meteorológica, foram analisadas ao longo do período experimental e em dois dias distintos:

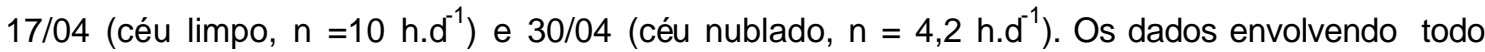
período experimental, de cada ambiente protegido (plástico leitoso, plástico leitoso + malha termo-refletora e plástico leitoso + malha preta) também foram relacionados com os dados da estação meteorológica, por meio de regressões lineares e posteriormente, procedeu-se da mesma forma com os dados diurnos e noturnos.

As variações da umidade relativa do ar no interior dos ambientes protegidos e na estação meteorológica foram analisadas ao longo do período experimental. Foi avaliado a variação horária da umidade relativa do ar, da pressão de saturação e da pressão atual de vapor d'água, nos ambientes protegidos e na estação meteorológica no dia 24/05.

A partir dos dados de evapotranspiração obteve-se a variação horária da evapotranspiração das plantas de Gérbera e a média diária, no decorrer de três dias (27/04, 10/05 e 18/05) e foi determinada e analisada as correlações entre a evapotranspiração média diária da Gérbera e os elementos meteorológicos: temperatura média diária, radiação solar global, umidade relativa e déficit de saturação para cada ambiente protegido (plástico leitoso, plástico leitoso + malha termo-refletora e plástico leitoso + malha preta).

A análise estatística das variáveis da cultura foi feita utilizando-se o delineamento inteiramente casualizado (DIC) adotando-se 3 tratamentos com 16 repetições e utilizando-se o teste de Tukey para comparação das médias (Figura 12). Para a análise estatística utilizou-se o programa estatístico Statistical Analysis System (SAS, 1992). 


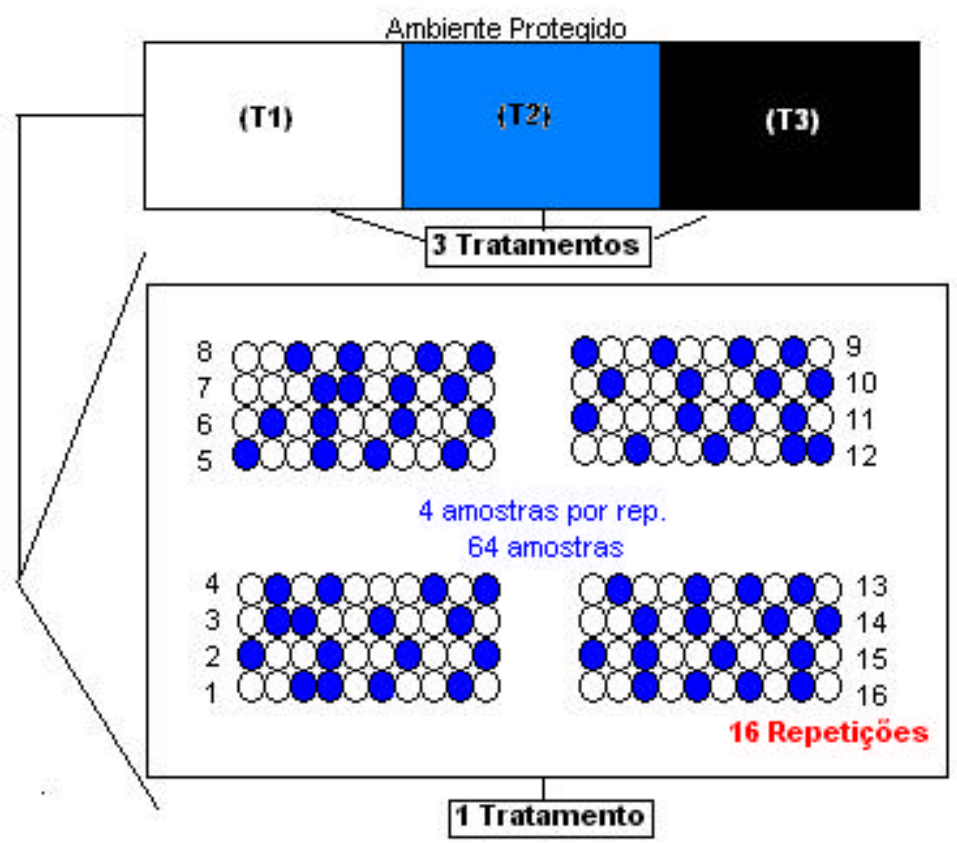

Figura 12 - Representação esquemática do delineamento experimental utilizado no experimento. Os círculos representam os vasos, sendo os círculos cheios os vasos amostrados para avaliação da cultura. 


\section{RESULTADOS E DISCUSSÃO}

\subsection{Variáveis Meteorológicas}

\subsubsection{Radiação Solar}

A radiação solar global e a fotossinteticamente ativa no interior de ambientes protegidos são significativamente menores do que as encontradas no ambiente externo, devido àatenuação provocada pela cobertura.

No presente estudo, verificou-se que, entre os ambientes avaliados, a maior transmitância, tanto para a radiação solar global $(\mathrm{Qg})$ (Figura 13), quanto para a radiação fotossinteticamente ativa (RFA) (Figura 14), ocorreu no ambiente coberto apenas com plástico leitoso, seguido pelo ambiente coberto com plástico + malha termo refletora e pelo ambiente coberto com plástico + malha preta.

Isto ocorreu porque a reflexão e a absorção promovidas pelas coberturas diminuem a incidência de radiação solar no interior do ambiente protegido (Seemann, 1979; Martin et al., 1982, Kurata, 1990, Sentelhas et al., 1997), devido ao tipo de cobertura (Al-Riah et al., 1989; Sentelhas et al, 1997; Critten \& Bailey, 2002) e cor do filme (Sentelhas et al., 1999). Isto explica a redução da radiação solar nos ambientes protegidos devido ao tipo de cobertura usado (plástico leitoso, plástico leitoso + malha termo refletora e plástico leitoso + malha preta) e à sua coloração (branco, branco + prateado e branco + preto). 


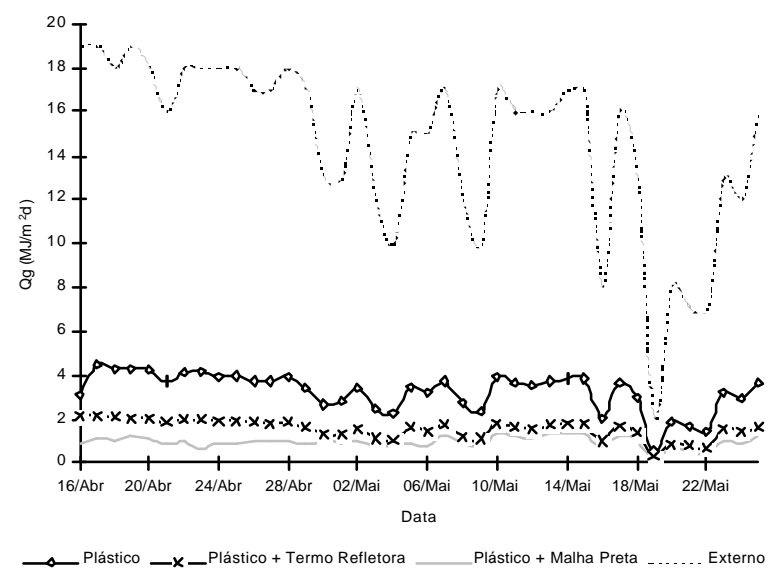

Figura 13 - Variação diária da radiação solar global $(\mathrm{Qg})$ no decorrer do período experimental, nos três ambientes protegidos (plástico leitoso, plástico leitoso + termo refletora e plástico leitoso + malha preta) e na estação meteorológica (ambiente externo).

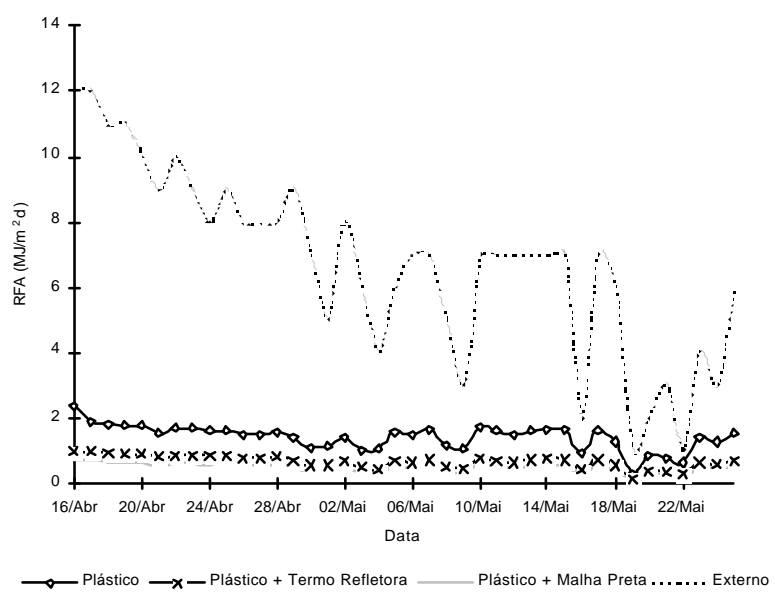

Figura 14 - Variação diária da radiação fotossinteticamente ativa (RFA) no decorrer do período experimental, nos três ambientes protegidos (plástico leitoso, plástico leitoso + termo refletora e plástico leitoso + malha preta) e na estação meteorológica (ambiente externo).

Analisando-se a variação diária de Qg e RFA para um dia de céu limpo (17/04) (Figuras 15 e 16) observa-se a mesma tendência encontrada nas Figuras 13 e 1 , ou seja, houve maior transmitância proporcionada pelo plástico leitoso em relação à combinação do plástico com malhas de sombreamento, o que também ocorreu para um dia de céu nublado (30/04) (Figuras 17 e 18). 


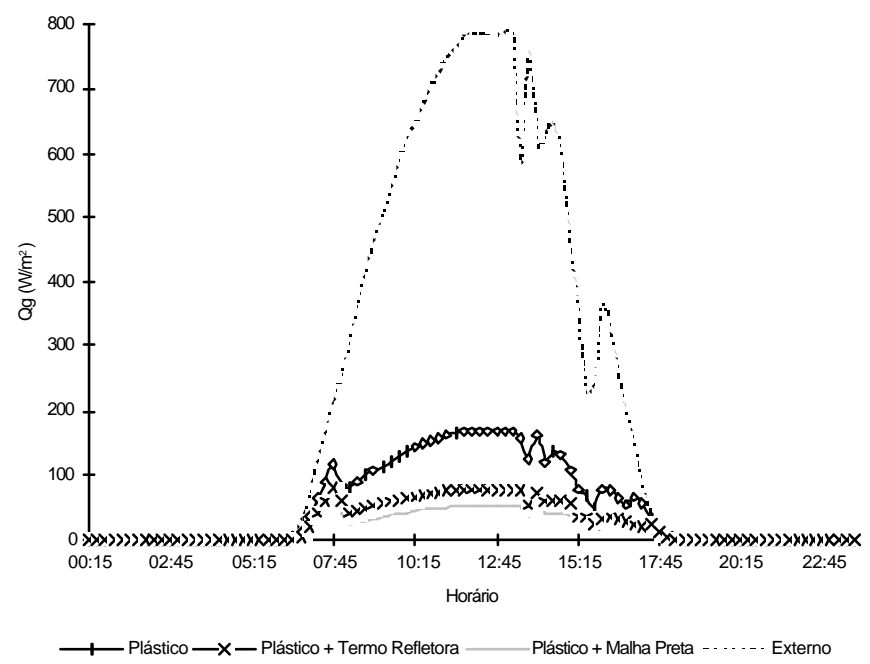

Figura 15 - Variação horária da radiação solar global $(Q g)$, para um dia de céu limpo (17/04), nos três ambientes protegidos (plástico leitoso, plástico leitoso + malha termo refletora e plástico leitoso + malha preta) e na estação meteorológica (ambiente externo).

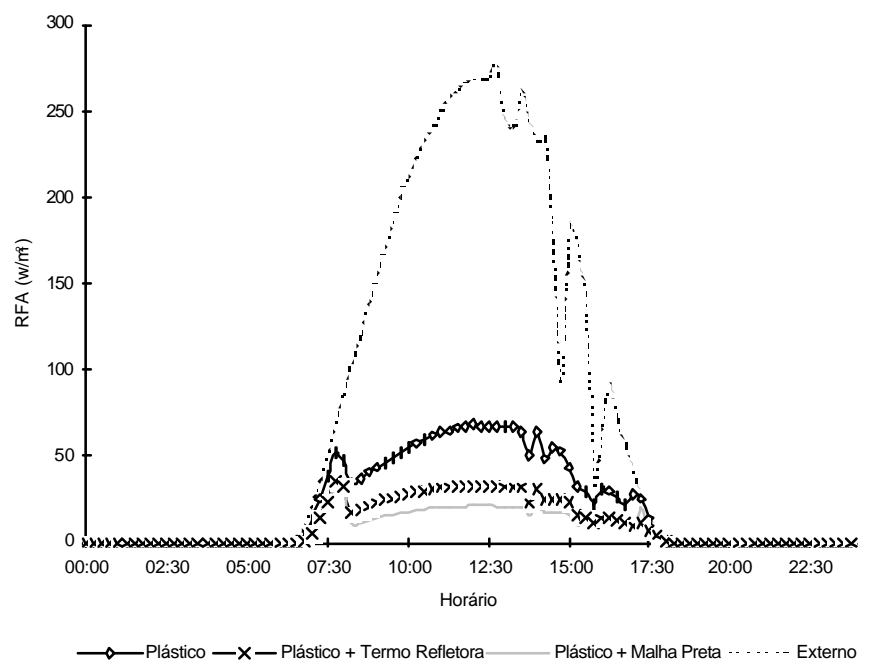

Figura 16 - Variação horária da radiação fotossinteticamente ativa (RFA), para um dia de céu limpo (17/04), nos três ambientes protegidos (plástico leitoso, plástico leitoso + malha termo-refletora e plástico leitoso + malha preta) e na estação meteorológica (ambiente externo). 


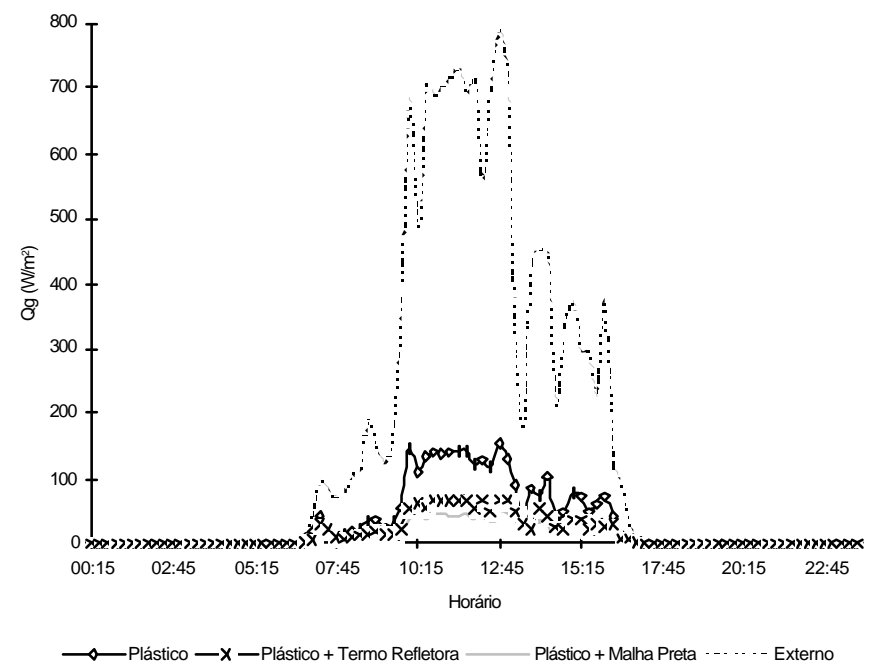

Figura 17 - Variação horária da radiação solar global (Qg), para um dia nublado (30/04), nos três ambientes protegidos (plástico leitoso, plástico leitoso + malha termo-refletora e plástico leitoso + malha preta) e na estação meteorológica (ambiente externo).

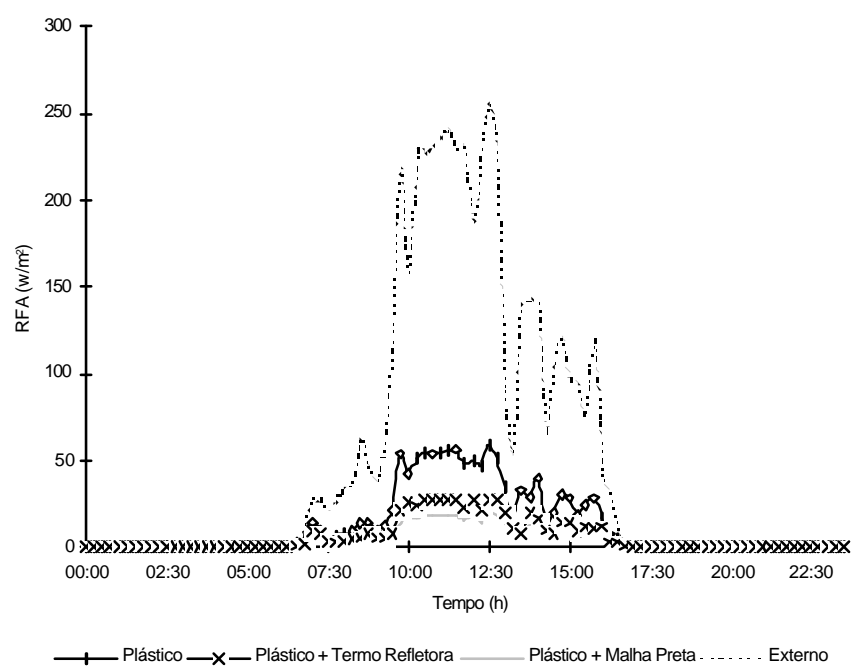

Figura 18 - Variação horária da radiação fotossinteticamente ativa (RFA), para um dia nublado (30/04), nos três ambientes protegidos (plástico leitoso, plástico leitoso + malha termo-refletora e plástico leitoso + malha preta) e na estação meteorológica (ambiente externo).

Comparando-se as transmitâncias das diferentes coberturas com a radiação solar global, em um dia de céu limpo e em dia de céu nublado, verifica-se que a transmitância sofreu pequenas alterações devido às condições atmosféricas. Para a cobertura com plástico leitoso a 
transmitância foi da ordem de 21 e $24 \%$. Já para as coberturas que combinavam o plástico leitoso com malhas de sombreamento a transmitância foi menor, sendo da ordem de 10 a $11 \%$ para plástico leitoso + malha termo-refletora e 7 e $8 \%$ para o plástico leitoso + malha preta.

Comparando-se aos resultados encontrados aos obtidos por Robledo \& Martin (1981) estudando o polietileno de baixa densidade (PEBD), onde a transmitância foi da ordem de 70 a $80 \%$ da radiação solar global e Ricieri \& Escobedo (1996) estudando do PEBD e PEBD associado a tela de sombreamento preta em túneis, onde os valores foram de 60 e $18 \%$, respectivamente, com os resultados obtidos no presente estudo, pode-se reforçar a afirmação de Baille (2001) de que para a redução da radiação solar no interior de ambientes protegidos pode-se usar filmes plásticos pintados com tinta branca ou associá-los a malha de sombreamento.
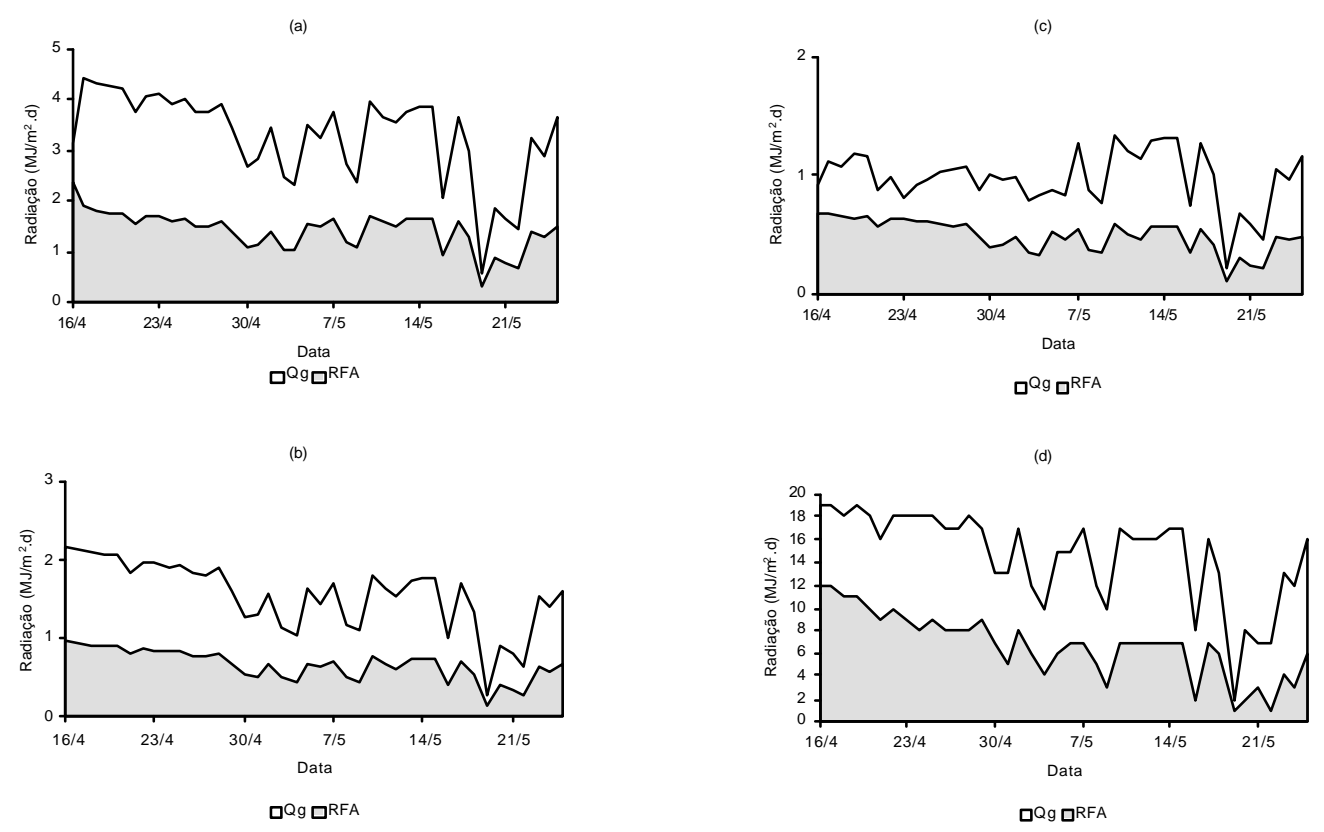

Figura 19 - Variação diária da radiação solar global $(\mathrm{Qg})$ e da fotossinteticamente ativa (RFA), nos três ambientes protegidos: plástico leitoso (a), plástico leitoso + malha termorefletora (b), plástico leitoso + malha preta (c) e na estação meteorológica (ambiente externo) (d), no decorrer do período experimental.

A relação entre a radiação fotossinteticamente ativa e a radiação solar global, ao longo do período experimental, pode ser observada nas Figuras 19 e 20 . Verifica-se que a RFA representa, em média de 43 a $44 \%$ da Qg, exceto no caso da cobertura constituída pelo plástico leitoso + malha preta, onde RFA/Qg foi da ordem de $51 \%$. De acordo com Kittas et al. (1999) o uso de plásticos não altera RFA/Qg em relação a condição externa, porém o uso de 
malha termo-refletora tende a diminuir essa relação, enquanto a malha preta apresenta-se neutra. Esses resultados diferem substancialmente dos encontrados no presente estudo, no qual se observou efeito nulo causado pela malha termo-refletora na relação RFA/Qg (Figura 20b) e tendência de aumento da referida relação sob a malha preta (Figura 20c), o que está de acordo com os resultados apresentados por Sentelhas et al. (1997).

Importante notar, que os estudos abordando a fação de RFA, radiação de grande importância para a planta, ainda são poucos e contraditórios, salientando sua importância no meio acadêmico, o que também é destacado por Kittas et al. (1999).
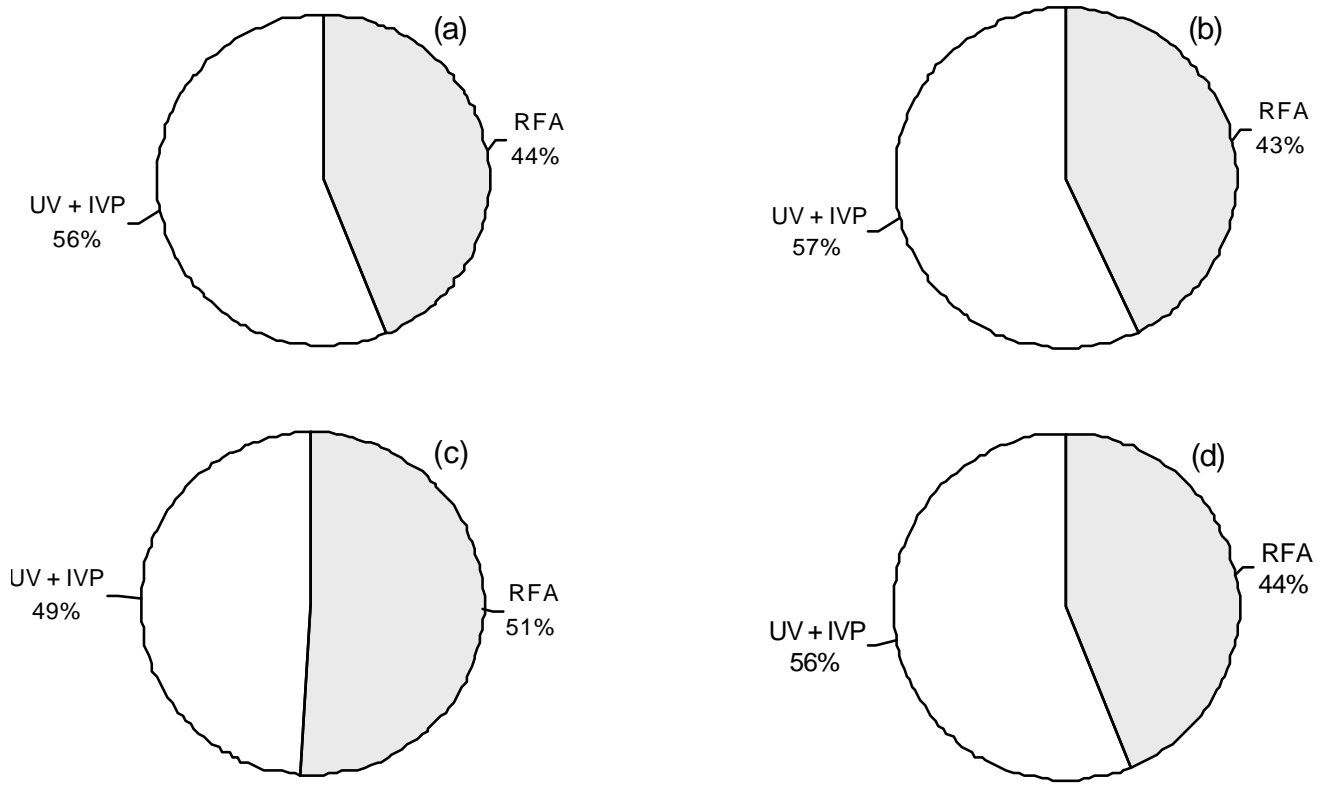

Figura 20 - Participação percentual da radiação solar global (Qg) em radiação fotossinteticamente ativa (RFA) e radiação ultra-violeta e infravermelho próximo (UV+IVP) nos três ambientes protegidos: (a) plástico leitoso, (b) plástico leitoso + termo-refletora, (c) plástico leitoso + malha preta e na (d) estação meteorológica (ambiente externo).

Essa partição também foi avaliada por meio da regressão linear entre os dados diários de RFA e Qg (Figura 21), chegando-se a resultados bastantes similares, ou seja uma maior relação $\mathrm{RFA} / \mathrm{Qg}$ abaixo da cobertura plástico leitoso + malha preta. Neste caso, RFA representa $42 \%$ de $\mathrm{Qg}$ nos ambientes cobertos por plástico leitoso e plástico leitoso + malha termo refletora (Figuras 21a e 21b), 49\% no ambiente abaixo do plástico leitoso + malha preta (Figura 21c) e 47\% no ambiente externo (Figura 21d). 

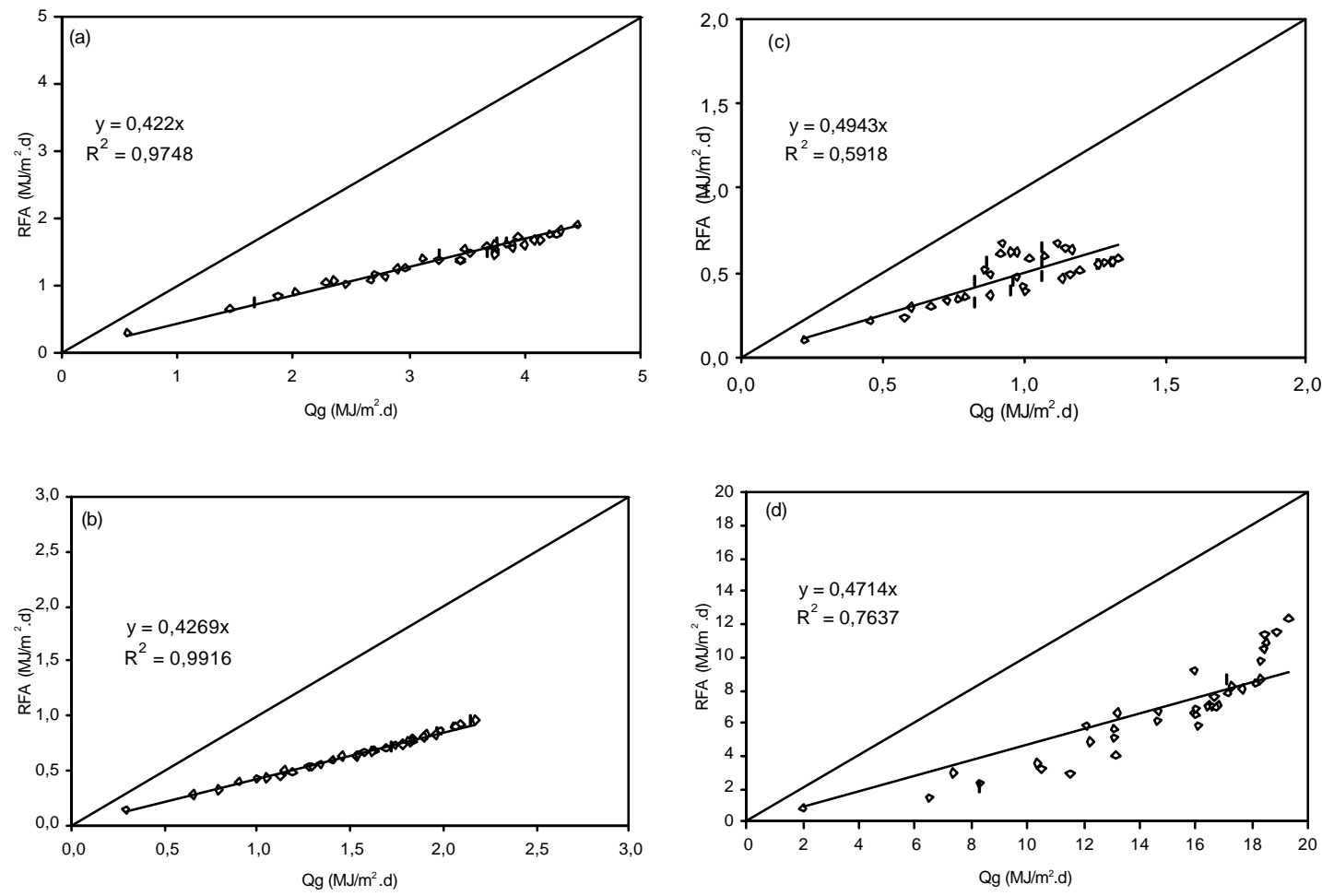

Figura 21 - Relação entre a radiação fotossinteticamente ativa e a radiação solar global nos ambientes cobertos por: plástico leitoso (a), plástico leitoso + malha termorefletora (b), plástico leitoso + malha preta (c) e na estação meteorológica (ambiente externo) (d).

\subsubsection{Temperatura do ar}

Ao longo do período avaliado, no interior dos ambientes protegidos ocorreram valores de temperatura do ar sempre superiores ao ambiente externo, concordando com resultados obtidos por Pezzopane (1997), Robledo \& Martim (1981), Mills et al. (1990) e Farias et al. (1993).

Observa-se na Figura 22 que a temperatura média do ar nos ambientes protegidos foi maior do que no ambiente externo para todo o período avaliado, havendo tendência de maior aquecimento sob o plástico leitoso, em média $6{ }^{\circ} \mathrm{C}$ a mais, em relação ao ambiente externo. Nos ambientes cobertos por plástico leitoso + malha termo-refletora e plástico leitoso + malha preta as temperaturas médias foram mais amenas, porém, ainda superiores, em média $3{ }^{\circ} \mathrm{C}$, ao observado na condição externa. 


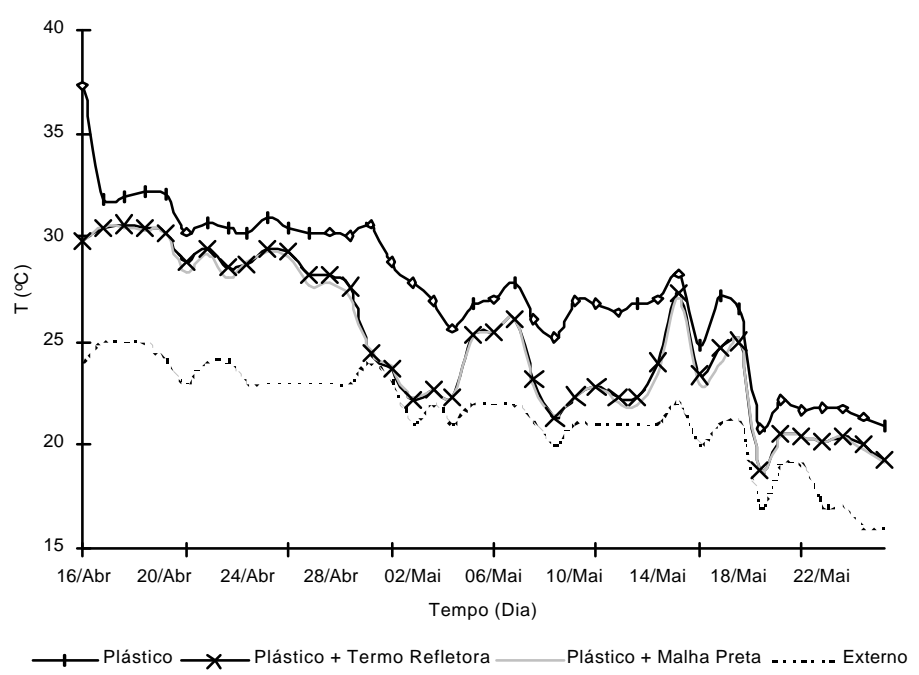

Figura 22 - Variação diária da temperatura média do ar (T), no decorrer do período experimental, nos três ambientes protegidos (plástico leitoso, plástico leitoso + malha termo-refletora e plástico leitoso + malha preta) e na estação meteorológica (ambiente externo).

Interessante notar que a variação da temperatura do ar dentro de ambientes protegidos é função do seu balanço de energia, portanto o aquecimento e resfriamento não dependem somente dos processos de incidência da radiação solar, mas também da reflexão e re-irradiação através dos objetos no interior do ambiente, convecção e condução através da cobertura e laterais, renovação de ar, evapotranspiração e troca do calor com solo (Cermeño, 1993). Os valores da temperatura média do ar são praticamente iguais nos dois ambientes protegidos cobertos com plástico leitoso associado æ̀s malhas de sombreamento, mesmo apresentando balanço de radiação diferentes. A cobertura plástico leitoso + malha preta, apesar de transmitir menor radiação, absorve mais e reflete menos do que plástico leitoso + malha termo-refletora, com isso a temperatura do ambiente coberto com plástico leitoso + malha preta possui uma tendência de transferir mais calor sensível por condução e convecção do que a malha termo-refletora, compensando assim as diferenças nos valores da radiação solar entre os dois ambientes, resultando numa mesma temperatura do ar.

Analisando-se os dados referentes aos dias 17/04, insolação (n) igual 10 h.d $d^{-1}$ (céu

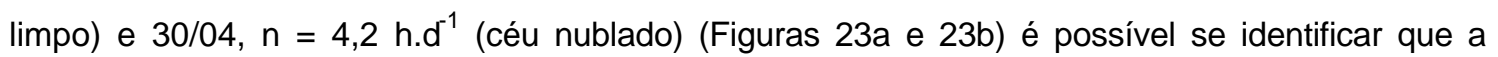
variação da temperatura do ar ao longo do dia apresenta padrão diferenciado em relação ao que é apresentado em nível das médias diárias (Figura 22).

Em condição de céu limpo (Figura 23a), observa-se que durante o período das 8 æ̀ 12 $\mathrm{h}$, aproximadamente, os ambientes cobertos por plástico leitoso + malhas (termo-refletora e 
preta) mostraram-se mais quentes do que o ambiente coberto por plástico leitoso e do que 0 ambiente externo. Comparando-se os ambientes sob plástico leitoso associados com as malhas e o ambiente coberto somente pelo plástico leitoso, verifica-se que as malhas instaladas internamente promovem uma barreira parcial ao movimento de convecção. Buriol et al. (1997) e Furlan (2001) observaram um gradiente de temperatura no interior do ambiente protegido, variando de um mínimo, próximo ao solo, até um máximo, perto do teto. Portanto, os ambientes cobertos com plástico leitoso associado æ̀ malhas de sombreamento tendem a apresentar temperaturas máximas logo abaixo das malhas, causando assim, valores de temperatura do ar, próximo aos sensores, maiores do que o ambiente sob o plástico leitoso.

No decorrer do dia, os raios solares passam a sofrer influencia direta da cobertura, devido a sua inclinação, e como o tipo de material também influencia a temperatura do ar no ambiente protegido (Seemann, 1979), tem-se que o ambiente com plástico leitoso, tendo a maior transmitância da radiação solar global, na ordem de $21 \%$, passa a ter maiores valores de temperatura do que os outros dois ambientes, o que acaba garantindo maiores valores de temperatura do ar durante a noite. Por outro, ado os ambientes com plástico + malha termorefletora e malha preta possuindo menor transmitância, da ordem de 10 e 7\%, respectivamente, apresentam menor aquecimento, por isso a partir das $13 \mathrm{~h}$ o padrão descrito entre as 8 e $12 \mathrm{~h}$ inverte-se, passando o ambiente coberto apenas com o plástico leitoso a apresentar valores de temperatura do ar mais elevadas, seguido pelos ambientes cobertos também pelas malhas (termo-refletora e preta) e pelo ambiente externo.

Em condição de céu nublado (Figura 23b), observa-se que a temperatura do ar no ambiente com plástico leitoso foi maior, em média $5^{\circ} \mathrm{C}$, quando comparada à da estação meteorológica. Porém nos ambientes cobertos com plástico leitoso associados às malhas de sombreamento, as temperaturas foram similares às da estação meteorológica, diferindo significativamente do que ocorreu no dia de céu limpo (Figura 23a), quando os valores de temperatura mostraram-se superiores nos três ambientes protegidos, em cerca de 7 e $6 \mathrm{C}$, respectivamente para os ambientes cobertos por plástico leitoso e plástico leitoso associado à malhas de sombreamento. Tal discrepância pode ser explicada pela alteração na variação da radiação solar global provocada pelas condições atmosféricas já citadas (Figura 17), a qual interfere diretamente sobre o balanço de radiação e de energia sob as diferentes coberturas dos ambientes. 

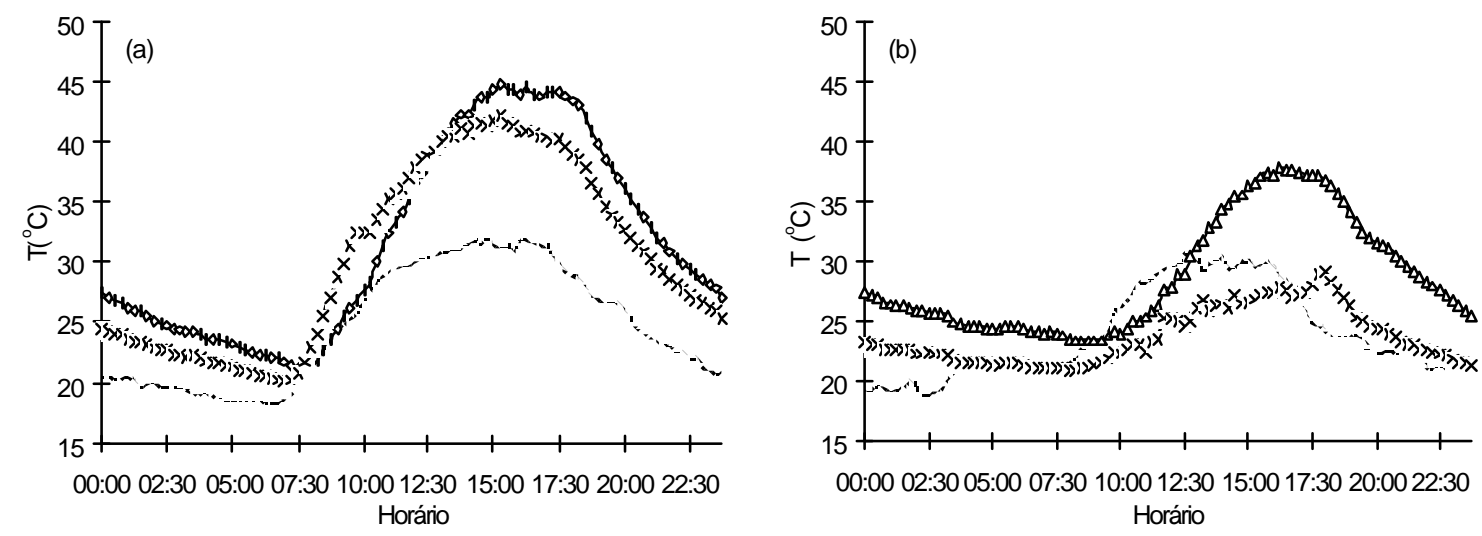

¿ Plástico — - Plástico + Termo Refletora ——Plástico + Malha Preta - - - - Externo

Figura 23 - Variação horária da temperatura do ar, (a) em um dia de céu limpo (17/04, n=10 h.d ${ }^{1}$ ) e (b) em um dia nublado (30/04, $n=4,2$ h. $\left.d^{-1}\right)$, nos três ambientes protegidos: plástico leitoso, plástico leitoso + malha termo-refletora e plástico leitoso + malha, preta e na estação meteorológica (ambiente externo).

As Figuras 24, 25 e 26 apresentam a relação entre a temperatura do ar dos ambientes protegidos e a temperatura externa. Observa-se, em média, que os valores da temperatura do ar no ambiente coberto por plástico foram $27 \%$ maior do que os do ambiente externo (Figura 24), enquanto que no ambiente coberto com plástico leitoso e malha termo-refletora esse acréscimo na temperatura foi da ordem de $15 \%$ (Figura 25) e no coberto com plástico leitoso e malha preta de $12 \%$ (Figura 26).

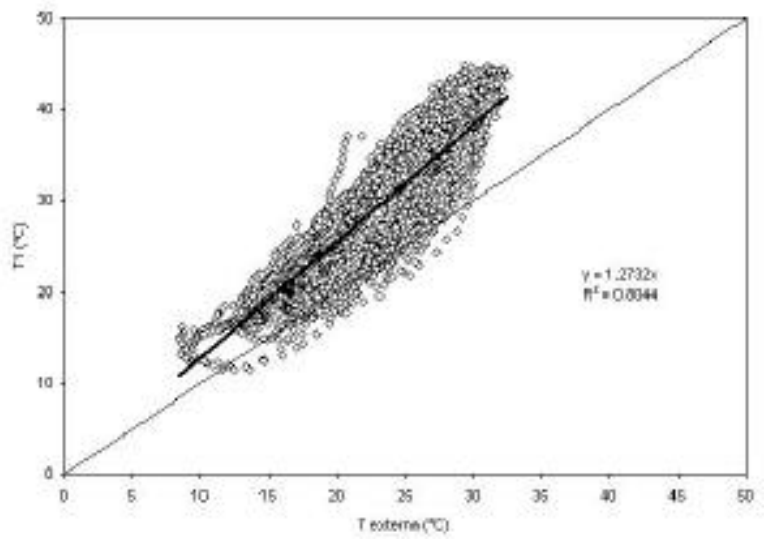

Figura 24 - Relação entre a temperatura do ar em ambiente coberto com plástico leitoso (T1) e a temperatura do ar na estação meteorológica (T externo), na escala de $15 \mathrm{~min}$ ao longo do período experimental. 


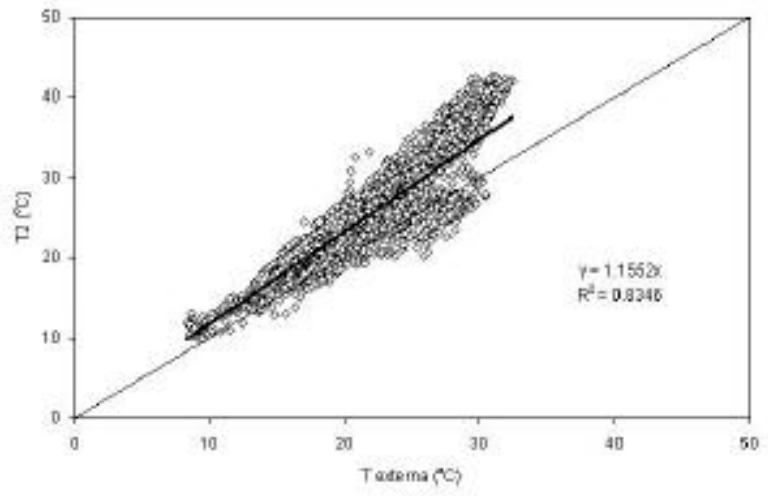

Figura 25 - Relação entre a temperatura do ar no ambiente coberto com plástico leitoso + malha termo-refletora (T2) e a temperatura do ar na estação meteorológica ( $T$ externo), na escala de 15 min ao longo do período experimental.

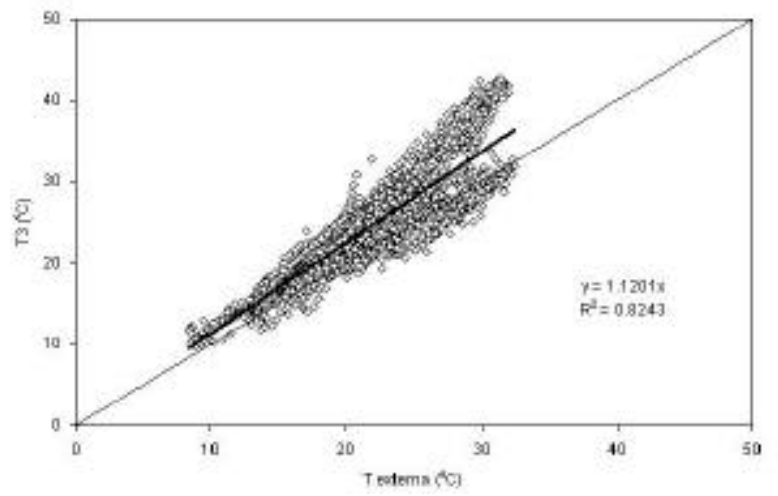

Figura 26 - Relação entre a temperatura do ar no ambiente coberto com plástico leitoso + malha preta (T3) e a temperatura do ar na estação meteorológica (T externo), na escala de $15 \mathrm{~min}$ ao longo do período experimental.

Analisando-se separadamente os períodos diurnos e noturnos, observa-se que no ambiente coberto pelo plástico leitoso os valores de temperatura do ar, em média, foram $23 \%$ e $33 \%$, respectivamente, maiores do que os encontrados no ambiente externo, como mostra as Figuras 27a e 27b.

No ambiente onde se utilizou plástico leitoso com a malha termo-refletora, os valores para o período diurno foram, em média, $15 \%$, e para o noturno $17 \%$ superiores ao ambiente externo (Figuras 28c e 28d), ao passo que no ambiente sob o plástico leitoso + malha preta as 
temperaturas, em média, foram 9 e $15 \%$ maiores do que as observadas externamente, respectivamente para os períodos diurno e noturno.
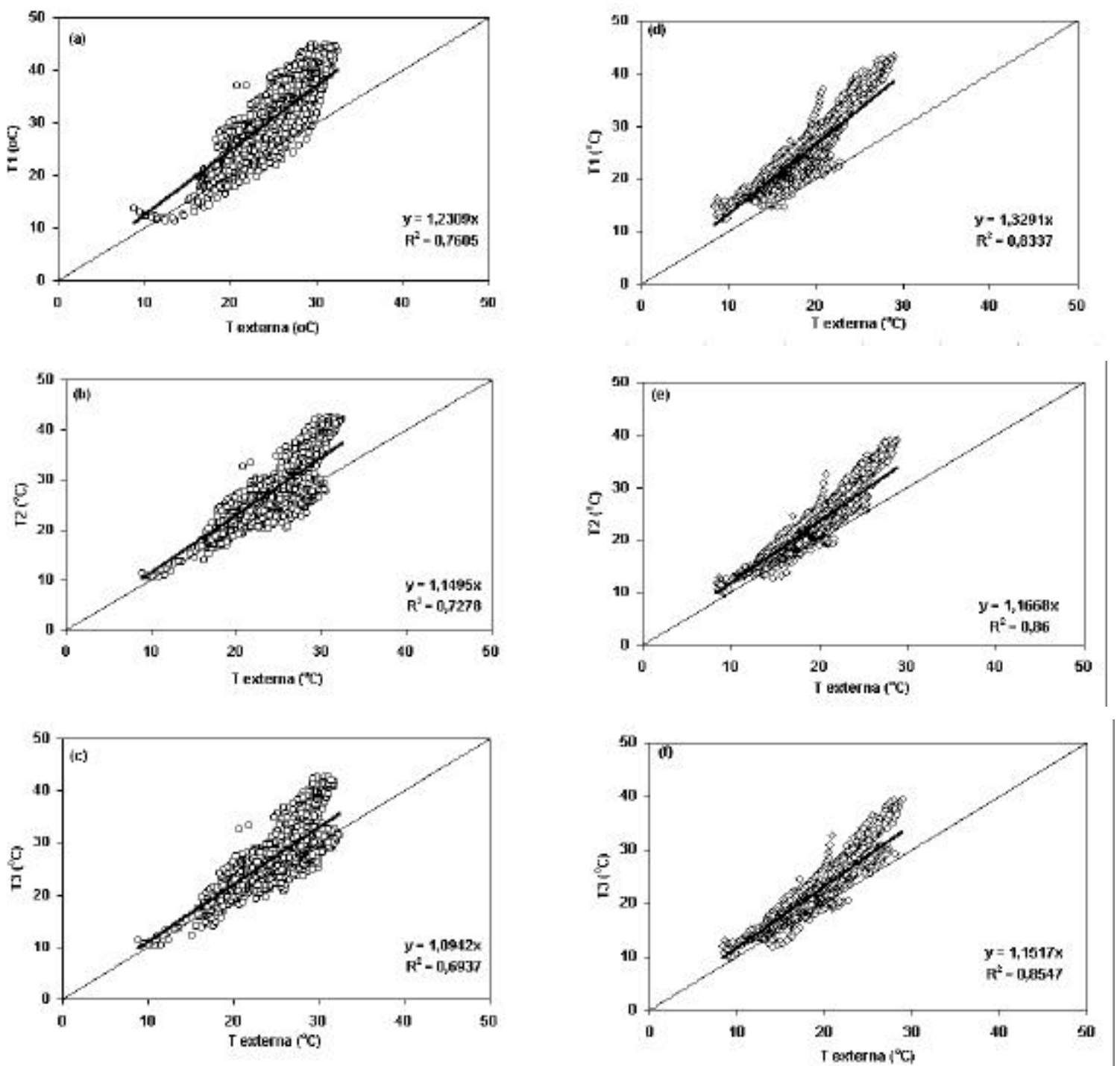

Figura 27 - Relação entre a temperatura do ar dos tratamentos e a temperatura do ar externa: (a), (c) e (e) Temperatura do ar diurna para os ambientes cobertos com plástico leitoso, plástico leitoso + malha termo-refletora e plástico leitoso + malha preta, respectivamente; (b), (d) e (f) temperatura do ar noturna para os tratamentos cobertos plástico leitoso, plástico leitoso + malha termo refletora e plástico leitoso + malha preta, respectivamente. 


\subsubsection{Umidade Relativa}

A variação da umidade relativa (UR) média ao longo do período experimental é apresentada na Figura 28. Verifica-se que durante todo o período os valores de UR no interior dos três ambientes protegidos foram similares, porém ligeiramente inferiores aos observados no ambiente externo. Isso se deve às diferenças de temperatura do ar entre os ambientes, que promoveram uma maior variação da UR no interior dos ambientes protegidos, como pode ser observado na Figura 29, onde verifica-se que durante o período noturno do dia 24/05 praticamente não houve diferença entre os ambientes protegidos e a condição externa, ao passo que durante o período diurno a UR foi sensivelmente maior na estação meteorológica, em razão da menor temperatura do ar nessa condição.



Figura 28 - Variação da umidade relativa média (UR), no decorrer do período experimental, nos ambientes protegidos (plástico leitoso, plástico leitoso + malha termo refletora e plástico leitoso + malha preta) e na estação meteorológica (ambiente externo).

Isso pode ser visualizado também por meio das Figuras 30a e 30b, nas quais observam-se as variações da pressão de saturação (es) e da pressão atual de vapor d'água (ea) nos ambientes protegidos e no posto meteorológico. Nota-se que durante o dia es nos ambientes protegidos atinge valores superiores ao ambiente externo o que resulta em uma menor UR, mesmo havendo aumento de ea, devido a retenção de vapor d'água pelo plástico. Resultados semelhantes aos aqui descritos também foram obtidos por Buriol et al. (2000), Viana (2000) e Furlan (2001). 


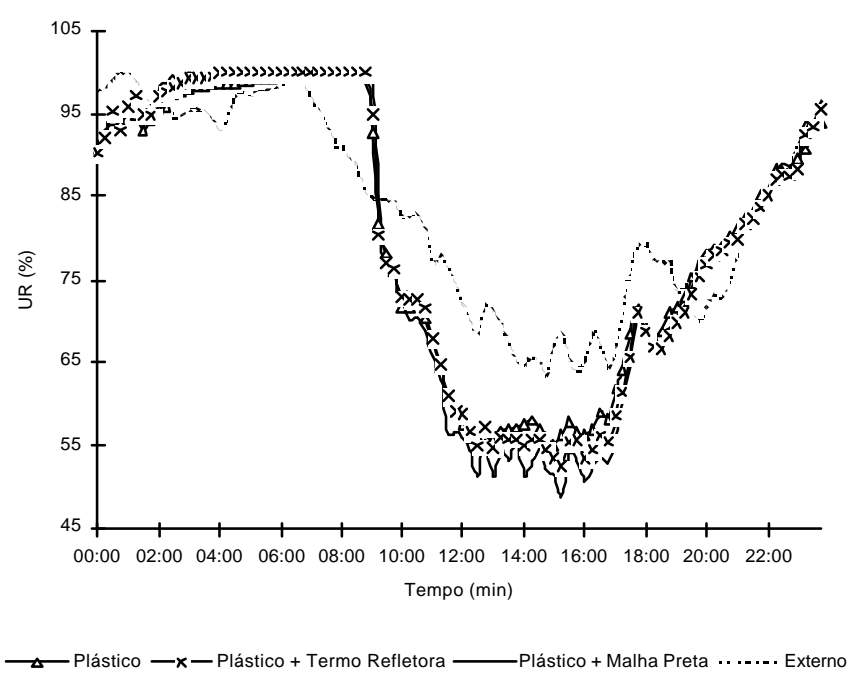

Figura 29 - Variação horária da umidade relativa do ar no dia 24/05 nos ambientes protegidos: plástico leitoso, plástico leitoso + malha termo-refletora e plástico leitoso + malha preta, e na estação meteorológica (ambiente externo).


¿-Plástico - - Plástico + Termo Refletora Plástico + Malha Preta - - - - Externo

Figura 30 - Variação horária: (a) da pressão de saturação (es) e (b) pressão atual de vapor (ea), no dia 24/05, nos ambientes protegidos: plástico leitoso, plástico leitoso + malha termo-refletora e plástico leitoso + malha preta, e na estação meteorológica (ambiente externo).

\subsubsection{Evapotranspiração da gérbera}

De acordo com os resultados apresentados na literatura, a evapotranspiração (ET) no interior de ambientes protegidos é inferior àquela que ocorre em condições externas. No 
entanto, as diferenças da ET entre ambiente protegido e condição externa irá depender de diversos fatores, especialmente daqueles relacionados ao tipo de cobertura utilizada no ambiente protegido. Isso pode ser observado na Tabela 3, onde são apresentados os dados de evapotranspiração média da Gérbera e os respectivos desvios padrões nos ambientes estudados.

Tabela 3. Evapotranspiração média da Gérbera $\left(m m \cdot d^{-1}\right)$, em cada ambiente protegido (plástico leitoso, plástico leitoso + malha termo-refletora e plástico leitoso + malha preta) nos dias 27/04, 10/05 e 18/05. Valores entre parentes representam o desvio padrão

\begin{tabular}{cccc}
\hline \multirow{2}{*}{ Dia } & \multicolumn{3}{c}{ ET } \\
\cline { 2 - 4 } & Plástico & Plástico + termo-refletora & Plástico + malha preta \\
\hline $27 / 04$ & $1,41( \pm 0,16)$ & $1,32( \pm 0,14)$ & $1,20( \pm 0,25)$ \\
$10 / 05$ & $1,25( \pm 0,14)$ & $1,07( \pm 0,22)$ & $0,94( \pm 0,19)$ \\
$18 / 05$ & $1,00( \pm 0,19)$ & $0,99( \pm 0,19)$ & $0,88( \pm 0,20)$ \\
\hline
\end{tabular}

Nos ambientes cobertos com plástico leitoso + malha termo-refletora e plástico leitoso + malha preta a ET observada foi, em média, 87,6 e 76,8\%, respectivamente, da ET obtida no ambiente sob plástico leitoso, o que a primeira vista obedeceu o padrão de variação da radiação solar (Figura 13).

Nas Figuras 31, 32 e 33 são apresentadas as variações da evapotranspiração média horária da Gérbera, ao longo dos três dias analisados. Nota-se que o ambiente coberto somente pelo plástico leitoso apresentou valores, na maioria das vezes, maiores do que nos ambientes cobertos pelo plástico associado æ̀ malhas de sombreamento, sendo que, no ambiente coberto por plástico leitoso + malha termo-refletora a ET foi maior do que a obtida no ambiente sob plástico leitoso + malha preta. 


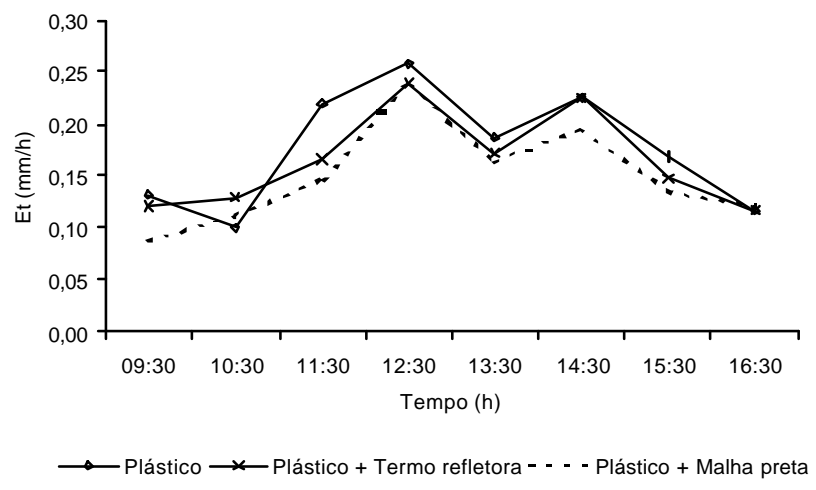

Figura 31 - Variação horária da evapotranspiração da Gérbera, no dia 27/04, nos tratamentos: plástico leitoso, plástico leitoso + malha termo-refletora e plástico leitoso + malha preta.

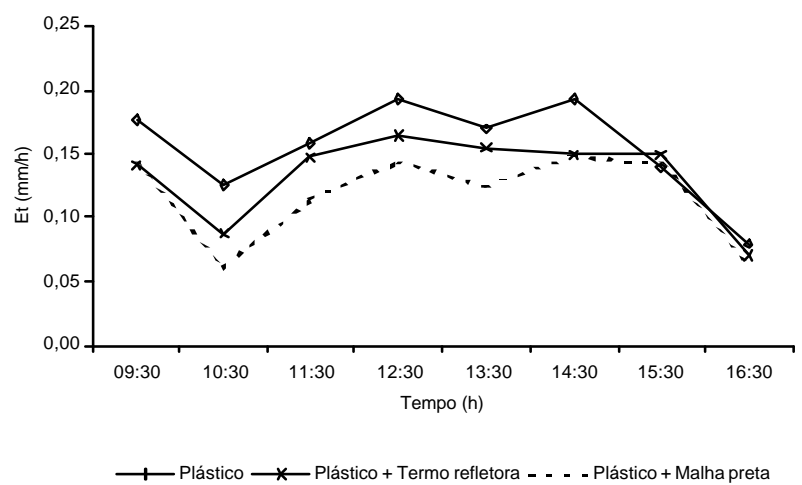

Figura 32 - Variação horária da evapotranspiração da Gérbera, no dia 10/05, nos tratamentos: plástico leitoso, plástico leitoso + malha termo-refletora e plástico leitoso + malha preta.

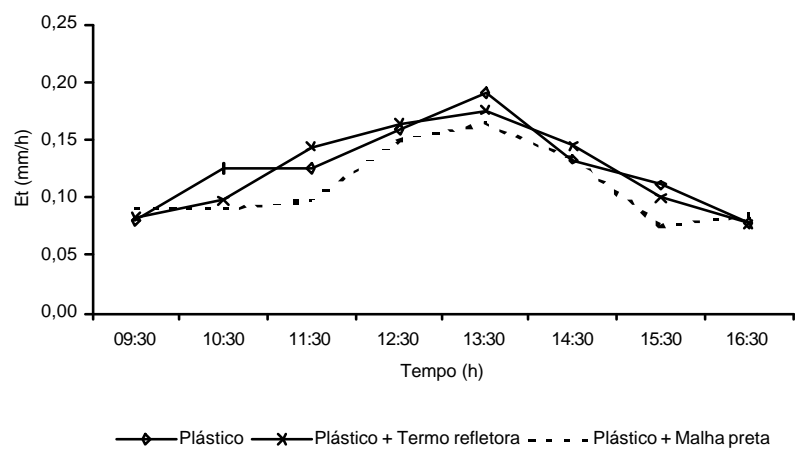

Figura 33 - Variação horária da evapotranspiração da Gérbera, no dia 18/05, nos tratamentos: plástico leitoso, pástico leitoso + malha termo-refletora e plástico leitoso + malha preta. 
Avaliando-se a relação entre a ET e os elementos meteorológicos em cada ambiente, verificou-se que houve correlação positiva com a temperatura média do ar, a radiação solar global e o déficit de saturação de vapor d'água e negativa com a umidade relativa do ar (Tabela 4). Em todos os casos a ET esteve diretamente correlacionada com a energia disponível no ambiente, sendo esta energia a principal fonte para o processo de evapotranspiração, seguida pela temperatura e umidade do ar (Furlan, 2001; Perreira et al. 2002). A atenuação da radiação solar global provocada pelos diferentes tipos de cobertura (plástico leitoso, plástico leitoso + malha termo-refletora e plástico leitoso + malha preta) é a principal causa das diferenças observadas na ET entre os três ambientes, assim como nos demais elementos meteorológicos, apesar das melhores correlações terem sido observadas com o déficit de saturação.

Tabela 4. Correlação entre a evapotranspiração diária da Gérbera em cada ambiente protegido: plástico leitoso (ET1), plástico leitoso + malha termo-refletora (ET2) e plástico leitoso + malha preta (ET3); e os elementos meteorológicos: temperatura média diária (Tmed), radiação solar global $(\mathrm{Qg})$, umidade relativa $(\mathrm{UR})$ e déficit de saturação de vapor d'água $(\Delta \mathrm{e})$.

\begin{tabular}{lccc}
\hline & & Evapotranspiração & \\
& ET1 & ET2 & ET3 \\
\hline T méd & 0,84 & 0,76 & 0,77 \\
Qg & 0,83 & 0,71 & 0,60 \\
UR & $-0,99$ & $-0,96$ & $-0,97$ \\
$\Delta$ e (es-ea) & 1,00 & 0,97 & 0,98 \\
\hline
\end{tabular}

\subsection{Variáveis da Cultura}

\subsubsection{Diâmetro e altura da planta}

Os valores do diâmetro e da altura média da Gérbera, cultivada nos diferentes ambientes protegidos, são apresentados nas Figuras 34a e 34b. Nota-se que os valores não diferiram significativamente, a $5 \%$, para os dados de diâmetro médio em nenhuma das avaliações (Tabela 5). No entanto, para os valores de altura média, nas avaliações dos dias 19/04 e 26/04, a análise estatística revelou uma diferença entre os valores do ambiente sob plástico leitoso e os dos ambientes cobertos com plástico leitoso æsociado às malhas de sombreamento, que por sua vez não diferiram significativamente entre si, a 5\% (Tabela 6). 
Os resultados obtidos revelaram que, a radiação solar, mesmo sendo diferenciada, não influenciou o diâmetro da planta, mas sim a altura, no início do ciclo. As plantas submetidas ao sombreamento de 60 a $80 \%$ tendem a ter sua área foliar aumentada, devido à redução da radiação solar que, conseqüentemente, promoverá o alongamento das folhas para a captação de maior quantidade de energia, garantindo assim, seus processos fotossintéticos (Carvalho \& Rocha, 1999).
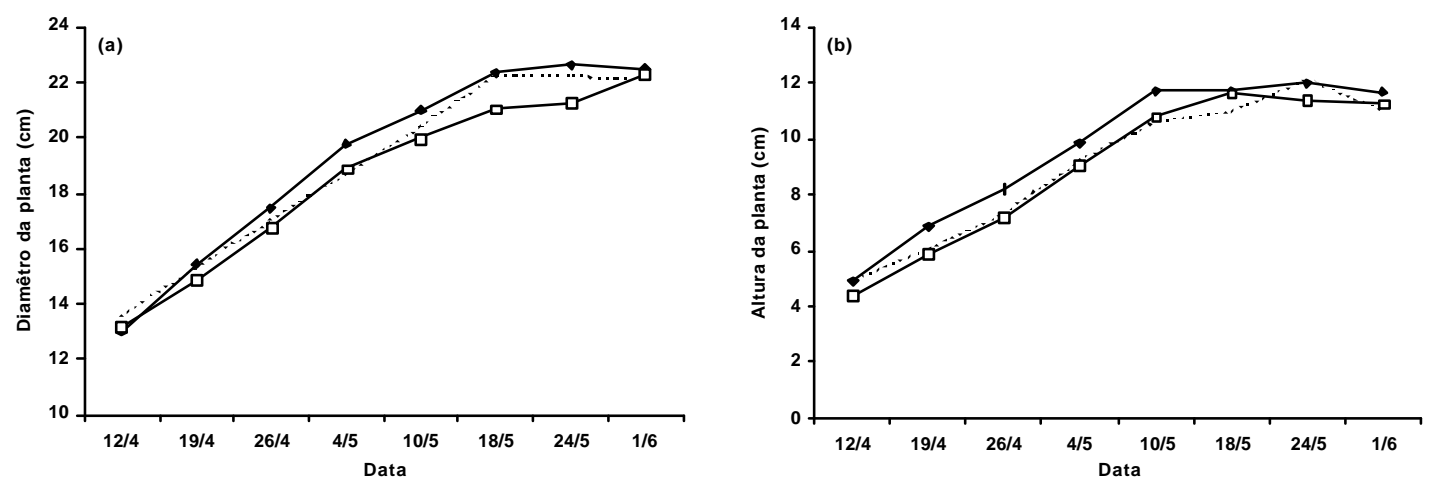

\section{$\longrightarrow$-Plástico ——Plástico + Termo Refletora - - - - Plástico + Malha Preta}

Figura 34 - Diâmetro médio (a) e altura média das plantas de Gérbera (b) nos ambientes protegidos: plástico leitoso, plástico leitoso + malha termo-refletora e plástico leitoso + malha preta, durante o período avaliado.

Tabela 5. Diâmetro médio das planta de Gérbera, nos três ambientes protegidos.

\begin{tabular}{lccc}
\hline & \multicolumn{4}{c}{ Diâmetro da planta $(\mathrm{cm})$} \\
\cline { 2 - 4 } Data & Plástico & $13,14 \mathrm{a}$ & $13,59 \mathrm{a}$ \\
\hline $12 / 4$ & $12,99 \mathrm{a}$ & $14,89 \mathrm{a}$ & $15,29 \mathrm{a}$ \\
$19 / 4$ & $15,46 \mathrm{a}$ & $16,74 \mathrm{a}$ & $17,08 \mathrm{a}$ \\
$26 / 4$ & $17,46 \mathrm{a}$ & $18,90 \mathrm{a}$ & $18,76 \mathrm{a}$ \\
$04 / 5$ & $19,78 \mathrm{a}$ & $20,01 \mathrm{a}$ & $20,40 \mathrm{a}$ \\
$10 / 5$ & $20,99 \mathrm{a}$ & $21,07 \mathrm{a}$ & $22,24 \mathrm{a}$ \\
$18 / 5$ & $22,39 \mathrm{a}$ & $21,26 \mathrm{a}$ & $22,24 \mathrm{a}$ \\
$24 / 5$ & $22,64 \mathrm{a}$ & $22,29 \mathrm{a}$ & $22,18 \mathrm{a}$ \\
$01 / 6$ & $22,54 \mathrm{a}$ & &
\end{tabular}

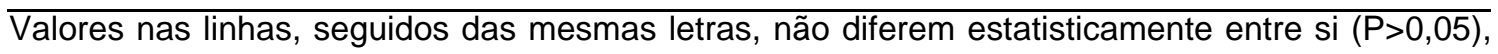
de acordo com o teste de Tukey. 
Tabela 6. Altura média das plantas de Gérbera nos três ambientes protegidos.

\begin{tabular}{lrrr}
\hline & \multicolumn{4}{c}{ Altura da planta $(\mathrm{cm})$} \\
\cline { 2 - 5 } Data & Plástico + Termo Refletora & Plástico + Malha Preta \\
\hline $12 / 4$ & $4,92 \mathrm{a}$ & $4,37 \mathrm{a}$ & $4,96 \mathrm{a}$ \\
$19 / 4$ & $6,89 \mathrm{a}$ & $5,87 \mathrm{~b}$ & $6,08 \mathrm{~b}$ \\
$26 / 4$ & $8,20 \mathrm{a}$ & $7,16 \mathrm{~b}$ & $7,33 \mathrm{~b}$ \\
$04 / 5$ & $9,86 \mathrm{a}$ & $9,08 \mathrm{a}$ & $9,25 \mathrm{a}$ \\
$10 / 5$ & $11,73 \mathrm{a}$ & $10,81 \mathrm{a}$ & $10,65 \mathrm{a}$ \\
$18 / 5$ & $11,75 \mathrm{a}$ & $11,63 \mathrm{a}$ & $11,02 \mathrm{a}$ \\
$24 / 5$ & $11,98 \mathrm{a}$ & $11,36 \mathrm{a}$ & $12,16 \mathrm{a}$ \\
$01 / 6$ & 11,66 a & $11,26 \mathrm{a}$ & $11,04 \mathrm{a}$
\end{tabular}

Valores nas linhas, seguidos das mesmas letras, não diferem estatisticamente entre si $(P>0,05)$, de acordo com o teste de Tukey.

\subsubsection{Número de folhas e botões florais}

Durante o período experimental, o ambiente coberto com plástico leitoso apresentou plantas com número médio de folhas e botões florais superiores aos ambientes sob plástico leitoso associado à malhas de sombreamento. Nas três primeiras avaliações as plantas sob as coberturas plástico leitoso + malha termo-refletora e plástico leitoso + malha preta apresentaram o mesmo número de folhas e botões florais. A partir da quarta semana de avaliação, as plantas sob o plástico leitoso + malha preta apresentaram menor número médio de folhas e botões florais em relação aos demais ambientes (Figuras 35a e 35b). Portanto as variações meteorológicas exerceram influência sobre as plantas de Gérbera, sendo a temperatura do ar o elemento que influenciou a emissão e o crescimento das folhas e também a precocidade da floração, concordando com INFOAGRO (2002).

Ao final da $16^{\text {a }}$ semana (Figura 36 ), o desenvolvimento das plantas sob o plástico leitoso, com relação ao número de botões florais, foi o mais rápido, seguido pelos ambientes cobertos pelo plástico leitoso + malha termo-refletora e pelo plástico leitoso + malha preta. 

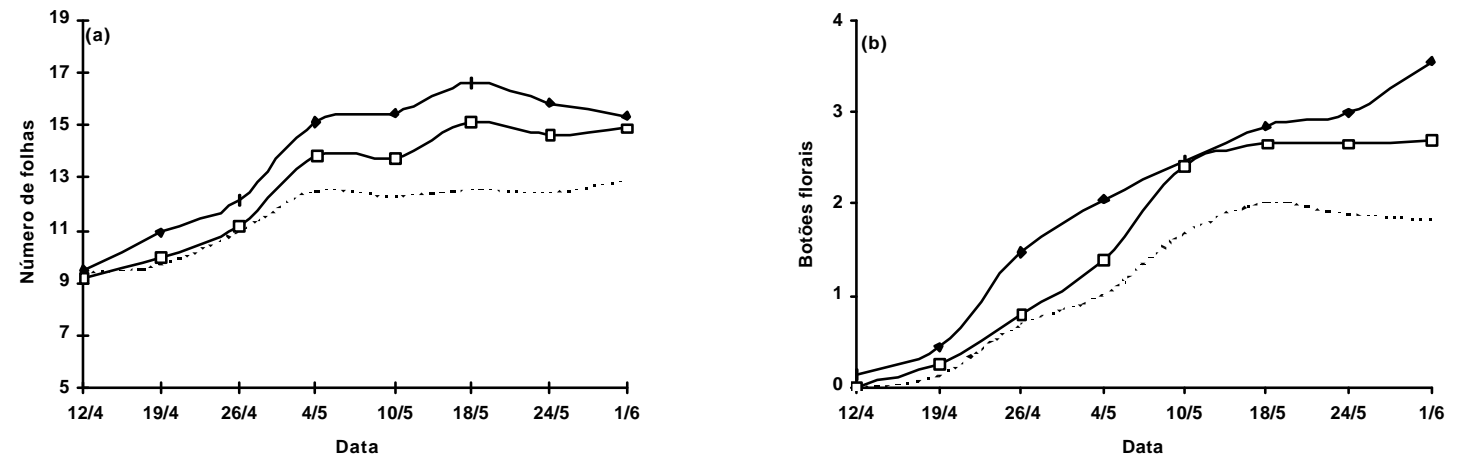

- Flästico $\rightarrow$ Flâstico + Temo Retletura -.... Flastico + Maha Frota |

Figura 35 - Número médio de folhas (a) e de botões florais (b) das plantas de Gérbera nos ambientes protegidos: plástico leitoso, plástico leitoso + malha termo-refletora e plástico leitoso + malha preta, durante o período avaliado.

(a)

(b)

(c)

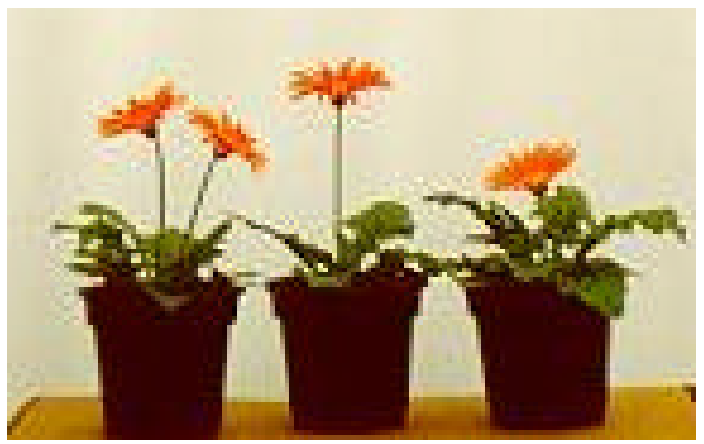

Figura 36 - Desenvolvimento da Gérbera jamesonii, cultivadas em ambientes protegidos: (a) plástico leitoso, (b) plástico leitoso + malha termo-refletora e (c) plástico leitoso + malha preta, após 16 semanas.

Ao se avaliar o número médio de folhas da planta pelo teste de Tukey $(P>0,05)$, confirmou-se que os valores das plantas sob o plástico leitoso foram superiores e que a maioria das avaliações diferiu significativamente dos ambientes sob o plástico leitoso associado æ̀ malhas de sombreamento. Nota-se, ainda, que nas primeiras avaliações as médias não diferiram significativamente, no entanto, no decorrer do período experimental, observou-se que para os três ambientes protegidos as médias diferiram significativamente entre si, especialmente no ambiente coberto pelo plástico leitoso + malha preta (Tabela 7). 
Tabela 7. Número médio de folhas da plantas de Gérbera nos três ambientes protegidos.

\begin{tabular}{lrrr}
\hline & \multicolumn{4}{c}{ Número de folhas } \\
\cline { 2 - 4 } Data & Plástico + Termo Refletora & Plástico + Malha Preta \\
\hline $12 / 4$ & $9,49 \mathrm{a}$ & $9,22 \mathrm{a}$ & $9,38 \mathrm{a}$ \\
$19 / 4$ & $10,91 \mathrm{a}$ & $10,01 \mathrm{ab}$ & $9,72 \mathrm{~b}$ \\
$26 / 4$ & $12,14 \mathrm{a}$ & $11,13 \mathrm{a}$ & $10,93 \mathrm{a}$ \\
$04 / 5$ & $15,14 \mathrm{a}$ & $13,84 \mathrm{~b}$ & $12,53 \mathrm{c}$ \\
$10 / 5$ & $15,45 \mathrm{a}$ & $13,76 \mathrm{~b}$ & $12,33 \mathrm{c}$ \\
$18 / 5$ & $16,59 \mathrm{a}$ & $15,10 \mathrm{a}$ & $12,60 \mathrm{~b}$ \\
$24 / 5$ & $15,90 \mathrm{a}$ & $14,64 \mathrm{a}$ & $12,46 \mathrm{~b}$ \\
$01 / 6$ & $15,37 \mathrm{a}$ & $14,92 \mathrm{a}$ & $12,93 \mathrm{~b}$
\end{tabular}

Valores nas linhas, seguidos das mesmas letras, não diferem estatisticamente entre si $(P>0,05)$, de acordo com o teste de Tukey.

Com relação ao número médio de botões florais (Tabela 8), a análise estatística também mostra que houve diferença significativa a partir da terceira avaliação (10 semanas após o plantio) entre os ambientes sob plástico leitoso e os sob plástico leitoso associado às malhas de sombreamento. No entanto, a partir da $12^{\mathrm{a}}$ semana (10/05) o número médio de botões florais apresentados nos ambientes cobertos por plástico leitoso e plástico leitoso + termo-refletora não diferiram significativamente entre si, indicando que não só a variação da temperatura do ar interferiu na emissão de botões florais na Gérbera, mas também a radiação solar incidente nos ambientes protegidos.

Tabela 8. Número médio de botões florais das plantas de Gérbera nos três ambientes protegidos.

\begin{tabular}{lccc}
\hline & \multicolumn{4}{c}{ Número de Botões } \\
\cline { 2 - 4 } Data & Plástico & Plástico + Termo Refletora & Plástico + Malha Preta \\
\hline $12 / 4$ & $0,13 \mathrm{a}$ & $0,00 \mathrm{a}$ & $0,00 \mathrm{a}$ \\
$19 / 4$ & $0,44 \mathrm{a}$ & $0,25 \mathrm{a}$ & $0,13 \mathrm{a}$ \\
$26 / 4$ & $1,48 \mathrm{a}$ & $0,79 \mathrm{~b}$ & $0,69 \mathrm{~b}$ \\
$04 / 5$ & $2,05 \mathrm{a}$ & $1,39 \mathrm{~b}$ & $1,01 \mathrm{~b}$ \\
$10 / 5$ & $2,46 \mathrm{a}$ & $2,41 \mathrm{a}$ & $1,68 \mathrm{~b}$ \\
$18 / 5$ & $2,85 \mathrm{a}$ & $2,65 \mathrm{a}$ & $2,02 \mathrm{~b}$ \\
$24 / 5$ & $2,98 \mathrm{a}$ & $2,66 \mathrm{a}$ & $1,89 \mathrm{~b}$ \\
$01 / 6$ & $3,56 \mathrm{a}$ & $2,69 \mathrm{ab}$ & $1,83 \mathrm{~b}$
\end{tabular}

Valores nas linhas, seguidos das mesmas letras, não diferem estatisticamente entre si $(P>0,05)$, de acordo com o teste de Tukey. 
Partindo-se do princípio que a exigência para comercialização da Gérbera, é de que cada vaso tenha pelo menos 2 botões florais abertos e um fechado (Steinberg, 2002) ${ }^{2}$, observou-se que nos ambientes cobertos por plástico leitoso e plástico leitoso + termo-refletora tal exigência mercadológica foi atendida.

\subsubsection{Diâmetro do capítulo e altura da haste}

Nas Figuras 37 a e 37b são apresentados os resultados relativos ao diâmetro médio do capítulo e altura média da haste.
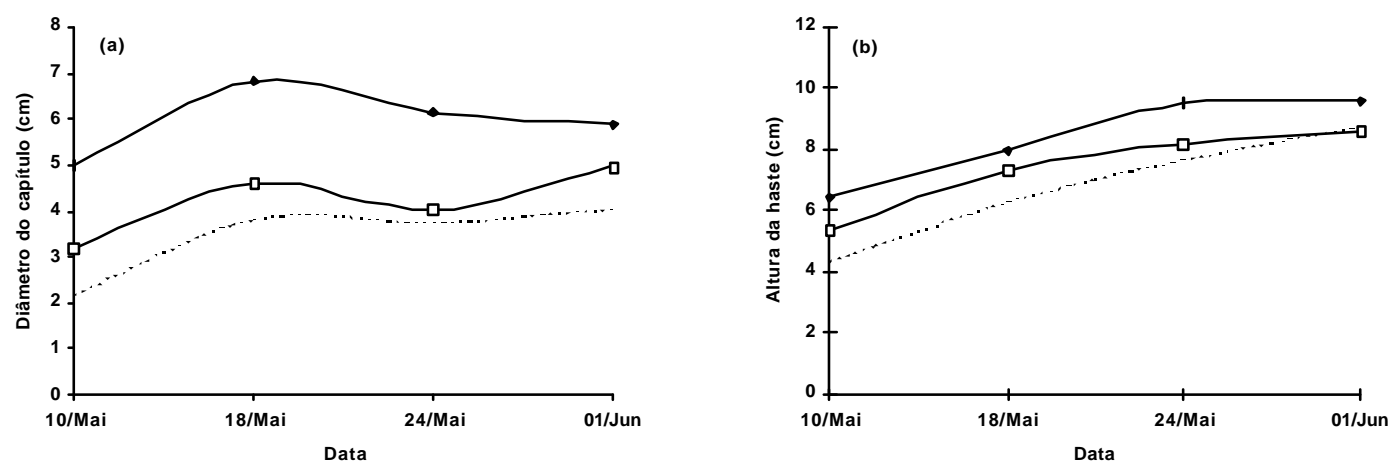

$\rightarrow$ Flástico $\rightarrow$ Flastico + Termo Rethatura -.... Flastico + Maha Freta |

Figura 37 - Diâmetro médio do capítulo (a) e altura média da haste (b) das plantas de Gérbera nos ambientes protegidos: plástico leitoso, plástico leitoso + malha termo-refletora e plástico leitoso + malha preta, durante o período avaliado.

Observa-se no caso do diâmetro do capítulo uma grande diferença entre o ambiente coberto pelo plástico leitoso em relação aos ambientes com plástico leitoso associado às malhas de sombreamento, revelando novamente a influência da radiação solar e da temperatura do ar no desenvolvimento das plantas de Gérbera, apesar de não ter havido diferença estatística significativa entre os três ambientes (Tabela 9).

\footnotetext{
${ }^{2}$ STEINBERG, E., (Syngenta Seeds LTDA) Comunicação pessoal, 2002.
} 
Tabela 9. Diâmetro médio do capítulo nos três ambientes protegidos.

\begin{tabular}{cccc}
\hline & \multicolumn{4}{c}{ Diâmetro capítulo $(\mathrm{cm})$} \\
\cline { 2 - 4 } Data & Plástico & Plástico + Termo Refletora & Plástico + Malha Preta \\
\hline $10 / 5$ & $4,99 \mathrm{a}$ & $3,20 \mathrm{a}$ & $2,19 \mathrm{a}$ \\
$18 / 5$ & $6,83 \mathrm{a}$ & $4,63 \mathrm{ab}$ & $3,84 \mathrm{~b}$ \\
$24 / 5$ & $6,13 \mathrm{a}$ & $4,01 \mathrm{a}$ & $3,76 \mathrm{a}$ \\
$01 / 6$ & $5,89 \mathrm{a}$ & $4,97 \mathrm{a}$ & $4,06 \mathrm{a}$ \\
\hline Valores & nas & &
\end{tabular}

$(P>0,05)$, de acordo com o teste de Tukey.

No caso da altura da haste observa-se que os valores médios não diferiram significativamente entre os ambientes estudados (Tabela 10). Tais resultados revelaram que, a quantidade de energia, mesmo sendo diferenciada nos três ambientes, não foi suficiente para provocar influencia na altura da haste. Considerando-se que o padrão A1 de comercialização requer haste com comprimento mínimo de $10 \mathrm{~cm}$ (Alves, 2002) ${ }^{3}$, as plantas dos três ambientes protegidos não se enquadraram nesse padrão, apresentando valores para os três ambientes, plástico leitoso, plástico leitoso + malha termo-refletora e plástico leitoso + malha preta, da ordem de 9,56, 8,63 e 8,78 cm, respectivamente, ocorrendo na $16^{a}$ semana após o plantio.

Tabela 10. Altura média da haste nos três ambientes protegidos.

\begin{tabular}{cccc}
\hline \multirow{4}{*}{ Data } & \multicolumn{4}{c}{ Altura da haste $(\mathrm{cm})$} \\
\cline { 2 - 4 } & Plástico & Plástico + Termo Refletora & Plástico + Malha Preta \\
\hline $10 / 5$ & $6,44 \mathrm{a}$ & $5,39 \mathrm{a}$ & $4,34 \mathrm{a}$ \\
$18 / 5$ & $7,95 \mathrm{a}$ & $7,35 \mathrm{a}$ & $6,30 \mathrm{a}$ \\
$24 / 5$ & $9,54 \mathrm{a}$ & $8,20 \mathrm{a}$ & $7,66 \mathrm{a}$ \\
$01 / 6$ & $9,56 \mathrm{a}$ & $8,63 \mathrm{a}$ & $8,78 \mathrm{a}$
\end{tabular}

Valores nas linhas, seguidos das mesmas letras, não diferem estatisticamente entre si $(P>0,05)$, de acordo com o teste de Tukey.

3 ALVES, L.C. (Veiling Holambra LTDA - Setor de Qualidade) Comunicação pessoal, 2002. 


\section{CONCLUSÕES}

Os resultados obtidos neste estudo permitem concluir que:

a) As coberturas constituídas de plástico leitoso, plástico leitoso + malha termorefletora e plástico leitoso + malha preta afetaram as variáveis meteorológicas diminuindo a radiação solar global e fotossinteticamente ativa, resultando em valores médios de transmitâncias da radiação solar na ordem de 23, 11 e 7\%, respectivamente.

b) A fração RFA/Qg foi a mesma para os ambientes plástico leitoso e plástico leitoso + malha termo-refletora, sendo maior no ambiente coberto pelo plástico leitoso + malha preta, em relação ao ambiente externo.

c) As coberturas plásticas detaram a temperatura do ar. O ambiente coberto com plástico leitoso apresentou, em média, $6^{\circ} \mathrm{C}$ a mais do que o ambiente externo e os ambientes cobertos pelo plástico leitoso associado æ̀s malhas de sombreamento $3^{\circ} \mathrm{C}$, em média.

d) Os três tipo de cobertura não afetaram a umidade relativa média diária e noturna, porém influenciaram a umidade relativa do ar durante o período diurno.

e) A evapotranspiração variou entre os ambientes protegidos, sendo maior sob o plástico leitoso e menor sob o plástico leitoso + malha preta.

f) A radiação solar e a temperatura do ar, afetaram o desenvolvimento da planta de Gérbera para cada ambiente, ocorrendo crescimento mais rápido no plástico leitoso e mais lento no plástico leitoso + malha preta.

g) As plantas de Gérbera cultivadas sob os ambientes protegidos cobertos pelo plástico leitoso e pelo plástico leitoso + malha termo-refletora atenderam à exigência do mercado quanto ao número de botões florais. Isso não ocorreu no ambiente sob o plástico leitoso + malha preta. Quanto a altura da haste, a Gérbera cultivada em ambiente protegido não apresentou valores médios superiores ao mínimo desejável, de $10 \mathrm{~cm}$.

h) Os microclimas proporcionados pelas coberturas constituídas por plástico leitoso e plástico leitoso + termo-refletora promoveram condições adequadas para o cultivo da Gérbera, durante o período entre o outono e o inverno. No entanto não pode-se afirmar que tais condições sejam representativas para todas as estações do ano, recomendando-se estudos 
futuros comparando-se diferentes materiais de cobertura em diferentes épocas do ano, visando um melhor entendimento do microclima na produção comercial de Gérbera. 


\section{REFERÊNCIAS BIBLIOGRÁFICAS}

ABAK, K.; BASÇETINÇELIK, A.; BAYTORUN, Ö. et al. Influence of double plastic cover and the thermal screens on greenhouse temperature, yield and quality of Tomato. Acta Horticulturae. v.366, p.149-154, 1994.

AKI, A. Retrospectiva 1999. Campinas: IBRAFLOR, 1999, 5p. (Mimeografado).

ALPI, A., TOGNONI, F. Cultivo en invernadero. 3.ed. Madri: Ediciones Mundi-Prensa, 1991, 347p.

AL-RIAHI, M.; AL-KARAGHOUL, I.; HASSON, A. W. Relations between radiation fluxes of a greenhouse in semi-arid conditions Agricultural and Forest Meteorology., v.44, p.32938,1989 .

ARRUDA, S.T.; OLIVETTE, M.P.A. CASTRO, C.E.F. Diagnóstico da floricultura do Estado de São Paulo. Revista Brasileira de Horticultura Ornamental, v.2, n.2, p.1-18, 1996.

BAILLE, A.; KITTAS, C.; KATSOULAS, N. Influence of whitening on greenhouse microclimate and crop energy partitioning. Agricultural and Forest Meteorology. v.107, p.293 - 306, 2001.

BAILLE, A.; TCHAMITCHIAN, M. Solar Radiation in Greenhouses. In: VARLET-GRANCHER, C.; BONHOME, R.; SINOQUET, $H$. Crop Structure and light microclimate: characterization and application. Paris: INRA Editions. 1993. 518p.

BAYTORUN, N.; ABAK, K.; TOKGÖZ, H.; ALTUNTAS, Ö. Effect of different greenhouse covering materials on inside climate and on the development of tomato plants. Acta Horticulturae. v.366, p.125-132, 1994.

BEDENDO, I.P. Ambiente e Doença. In: BERGAMIM FILHO, A.; KIMATI, H.; AMORIM, L. Manual de Fitopatologia. São Paulo: Agronômica Ceres, 1995. v.1, p.331-341.

BOULARD, T., ÆUILLOLEY, P., KTTAS, C. Natural ventilation of six greenhouse and tunnel types. Journal of Agricultural Engineering Research. v.67, p.249 - 266, 1997.

BOULARD, T.; MENESES J F MERMIER, M; PAPADAKIS. G. The mechanisms involved in the natural ventilation of greenhouses. Agricultural and Forest Meteorology, v.79, n.1/2, p.6177, 1996.

BURIOL, G. A., HELDWEIN, A. B., STRECK, N. A., SCHNEIDER, F.M., ESTEFANEL, V., DALMAGO, G.A. Gradiente vertical de temperatura do ar no interior de estufas plásticas. In: CONGRESSO BRASILEIRO DE AGROMETEOROLOGIA 10., Piracicaba, 1997. Anais Piracicaba: Sociedade Brasileira de Agrometeorologia, 1997, p.471-472.

BURIOL, G. A., RIGHI, E.Z., SCHNEIDER, F.M., STRECK, N. A., HELDWEIN, A. B., ESTEFANEL, V. Modificação da umidade relativa do ar pelo uso e manejo da estufa plástica. Revista Brasileira de Agrometeorologia, v.8, n.1, p.11-18, 2000. 
BURN, R.; LAGIER, I. A new greenhouse structure adapted to mediterranean growing. Acta Horticulturae, v.170, p.37-46, 1985.

CASTRO, C.E.F., Cadeia produtiva de flores e plantas ornamentais. Revista Brasileira de Horticultura Ornamental, v.4, n.1/2, p.1-46, 1998.

CERMEÑO, Z. S. Cultivo de plantas hortícolas em estufa. Litexa-Portugal: Ed. Lisboa, 1993, $366 p$.

COKSHULL, K. E.; GRAVES, C. J.; CAVE, R. J. The influence of shading on yield of glasshouse tomatoes. Journal of Horticultural Science, v.67, p.11-24, 1992.

CRITTEN, D. L.; BAILEY, B. J. A review of greenhouse engineering developments during the 1990s. Agricultural and Forest Meteorology, v.112, p.1-22, 2002.

DOORENBOS J.; PRUITT, W.O. Necessidades hídricas das culturas. Trad. de H.R. Gheyi e J.E.C. Metri e F.A.V. Damasceno. Campina Grande: UFPB, 1997. 204p.

FACCIOLI, G.G. Determinação da evapotranspiração de referência e da cultura da alface em condições de casa de vegetação, em Viçosa, MG. Viçosa, 1998, 85p. Dissertação (Mestrado), Universidade Federal de Viçosa.

FARIA JUNIOR, M.J.A. Avaliação de diferentes arquiteturas de estufas, coberturas do solo com filme plástico, em híbridos de Pimentão (Capsicum annuum L.). Jaboticabal, SP, 1997, 102p. Tese (Doutorado) - Faculdade de Ciências Agrárias e Veterinárias, Campus de Jaboticabal, Universidade Estadual Paulista, "Julio Mesquita Filho".

FARIAS, J. R., BERGAMASCHI, H., MARTINS, M. A. B., OLIVEIRA, A. C. B. Alterações na temperatura e umidade relativa do ar provocadas pelo uso de estufa plástica. Revista Brasileira de Agrometeorologia, v.1, n.1, p.51-62,. 1993.

FARIAS, J.R.; BERGAMASCHI, H.; MARTINS, S,R, Evapotranspiração no interior de estufas plásticas. Revista Brasileira de Agrometeorologia, v.2, p.17-22, 1994.

FEUILLOLEY, P.; MEKIKDJIAN, C.; SEVILA, F. Static aeration in greenhouses. Acta Horticulturae, v.281, p.175-182, 1990.

FNP CONSULTORIA \& COMERCIO. AGRIANUAL 1999: anuário de agricultura brasileira. São Paulo, 1999. p.435.

FOLEGATTI, M. V., SCATOLINI, M. E.; PAZ, V. P. S.; et al. Efeitos da cobertura plástica sobre os elementos meteorologicos e evapotranspiração da cultura de crisântemo em estufa.Revista Brasileira de Agrometeorologia, v.5, n.2, p.155-163, 1997.

FURLAN, R.A. Avaliação da nebulização e abertura de cortinas na redução da temperatura do ar em ambiente protegido. Piracicaba, 2001, 146p. Tese (Doutorado) - Escola Superior de Agricultura "Luiz de Queiroz", Universidade de São Paulo.

GATES, D.M. Energy exchange and transpiration. Berlim: Springer-Verlag. 1976, p.137-147.

GERSTENBERGER, K; SIGMUND, I., Europen Horticultural Statistics - Non - Edible Products, Hannover-Germany: Association Internationale des producteurs de L' Horticulture, Institut fur Gartenbauokonomie University, 1980. p.173. (Institut fur Gartenbauokonomie University, 28)

GIACOMELLI, G.A., TING, K.C., PANIGARAHI, S. Solar PAR vs. Solar total radiation transmission in a greenhouse. Transactions of the ASAE, v.31, p.1540-1543, 1988.

GONZALES, A.M. Ahorro energético y materiales de cobertura para cultivos hortícolas. In: CURSO INTERNACIONAL DE HORTICULTURA INTENSIVA (COMESTIBLE $Y$ ORNAMENTAL) EN CLIMAS ARIDOS, 4., Murcia, España, 1985. Apostilas. Murcia: Ministerio de Agricultura, Instituto Nacional de Investigaciones Agrarias. v.2, 1985. p.258. 
GOTO, R.; TIVELLI. S. W. et. al., Produção de hortaliças em ambiente protegido: condições subtropicais. São Paulo: Fundação Editora UNESP, 1998. 319p.

GUIMARÃES, J.; ILHA, F.; ALMEIDA, R. Flores: Exuberância e delicadeza conquistam mercados. Exportar \& Gerenciar, v.2, n.17, p.20-23, 2000.

HANAFI, A.; PAPASOLOMONTOS, A. Integrated production and protection under protected cultivation in the Mediterranean region Biotechnology Advances v.17, n.2/3, p.183-203, Sep, 1999.

HARDOIN, P.C. Qualidade do ar. Sistemas de ventilação natural e artificial na exploração avícola. IN: SIMPÓSIO INTERNACIONAL SOBRE AMBIÊNCIA E INSTALAÇÃO NA AVICULTURA INDUSTRIAL, Campinas, SP. Livro de textos. Campinas: FACTA, 1995. p.89-98.

IBRAFLOR. Programa Brasileiro de exportações de flores e plantas ornamentais. Informativo Ibraflor. n.23, v.7, 2001. p.8. (Suplemento Informativo).

INFOAGRO, El Cultivo de la Gerbera. URL://www.infoagro.com., (15 mar. 2002).

KITTAS, C., BAILLE, A., GIAGLARAS, P. Influence of covering material and shading on the spectral distribution of light in greenhouse. Journal of Agricultural Engineering Research. v.73, p.341 - 351, 1999.

KURATA, K. Role of reflection in light transmissivity of greenhouses. Agricultural and Forest Meteorology, n.52, p.319-331, 1990.

LEFFRING, L., Effects of daylength and temperature on shoot and flower production of Gerbera. Acta Horticulturae, v.51, p.263-265, 1975.

LEPORI, G., FRACESCHETTI, U., NASSI, M.O., The effects of solar radiation on some genotypes of gerbera, in EUCARPIA MEETING ON GENETICS AND BREEDING OF CARNATION AND GERBERA, April 1978, Alassio, Italy, Quagliotti, L. and Baldi, A., Turin, Italy: Institute of Plant Breeding and Seed Production, 1979. p.245-254.

MARIN, F.R., ANGELOCCI, L.R., COELHO FILHO, M.A., VILLA NOVA, N.A. Construção e avaliação de psicrômetro aspirado de termopar. Scientia Agricola, v.58, n.3, jul, 2001.

MARTIN, E.C., NOVOA, A.C., GOMES, S.J. Estudio comparativo de las propiedades de diversos materiales como cubierta en cultivos protegidos. Revista de Plásticos Modernos, n.308, p.185 -189, 1982.

MARTINEZ GARCIA, P.F. Características climáticas do los invernaderos de plástico. Madrid: Instituto Nacional de Investigaciones Agrarias - INA. 1978. 48p. (Hojas Técnicas, 19)

MARTINS S.R; GONZALES, J.F, Evapotranspiração e respostas fisiológicas do feijão-vagem cultivado em substrato em estufa com sistema de ventilação/calefação. Revista Brasileira de Agrometeorologia, v.3, p.31-37, 1995b.

MARTINS, S.R.; GONZALES, J.F. Avaliação do resfriamento em estufa plástica mediante sistema de ventilação e nebulização. Revista Brasileira de Agrometeorologia, v.3, p.1318, 1995a.

MASCARINI, L.. El cultivo de la gerbera en sustrato. Revista Horticultura Internacional. n. 19, p. 86-88, 1998.

McCREE, K. J. The action spectrum, absorptance and quantum yield of photosynthesis in crop plants. Agricultural Meteorology, v.9, p.191-216, 1972.

MEDEIROS, J.F.; PEREIRA, F.A.C.; FOLEGATTI, M.V.; PEREIRA, A.R.; VILLA NOVA, N.A. Comparação entre evaporação de tanque classe $A$ padrão e em minitanque, instalados em estufa e estação meteorológica. In: CONGRESSO BRASILEIRO DE 
AGROMETEOROLOGIA, Piracicaba, 1997. Anais. Piracicaba: Sociedade Brasileira de Agrometeorologia, 1997, p.228-230.

MILLS, P.J.W., SMITH, I.E., MARAIS, G. A greenhouse design for a cool subtropical climate with mild winters based on microclimatic measurements of protected environments. Acta Horticulturae., n.281, p.83-94, 1990.

MONTERO, J. I; CASTILHA, N.; GUTIERREZ DE RAUÉ, E.; BRESTONES. F. Climate under plastic in the Almeira area. Acta Horticulture, v.170, p.277-234, 1985.

NASCIMENTO FILHO, M. F.; MOURA, M. A. L.; SOUZA, D. K. S; BRAGA, M. B., Caracterização microclimática em diferentes estufas plásticas com hostaliças. In: CONGRESSO BRASILEIRO DE AGROMETEOROLOGIA. Piracicaba, SP. 1997. Anais, Piracicaba: Ed. Sociedade Brasileira de Agrometeorologia, 1997. p 488-491.

OLIVEIRA, M.R.V. O emprego de casas de vegetação no Brasil: vantagens e desvantagens. Pesquisa Agropecuária Brasileira, v.30, n.8, p.1049-1060, 1995.

PEREIRA, A. R.; ANGELOCCI, L. R.; SENTELHAS, P. C. Agrometeorologia: fundamentos e aplicações práticas. Guaíba: Agropecuária, 2002. 478p.

PEZZOPANE, J.E.M.; PEDRO JUNIOR, M. J.; ORTOLANI,A.A MEYER, N. Radiação liquida e temperatura de folha no interior de estufa com cobertura plástica, durante o período noturno. Revista Brasileira de Agrometeorologia v.3, p.1-4, 1995.

RAULT, P.A. A tunnel greenhouse adapted to the tropical lowland climate. Acta Horticulturae., v.281, p.95-103, 1990.

REIS, N.V.B. Diferencial entre os parâmetros de temperaturas interna e externa de uma estufa modelo teto em arco - efeito guarda chuva. In: CONGRESSO BRASILEIRO DE AGROMETEOROLOGIA 10; Piracicaba, 1997. Anais. Piracicaba. Sociedade Brasileira de Agrometeorologia, 1997, p.465-467.

REIS, N.V.B.; CARRIJO, O.A. Estufa, material de cobertura e cortinamento - durabilidade e transparência à radiação solar. (compact disc). In: CONGRESSO BRASILEIRO DE AGROMETEOROLOGIA, 11; Florianópolis, 1999. Florianópolis: Sociedade Brasileira de Agrometeorologia, 1999.

RICIERCI, R.P., ESCOBEDO, J.F., Solar radiation levels in a greenhouse with sloping roofs of SOMBRITE and polyethylene. Energia na Agricultura. v.11, n.2, p.8-26, 1996.

RIGHI, E. Z. Consumo Hídrico do Tomateiro (Lycopersicon esculentum Mill.) cultivado em estufa plástica e sua relação com variáveis meteorológicas em Santa Maria, RS. Piracicaba, 2000. 69p. Dissertação (Mestrado) - Escola Superior de Agricultura Luiz de Queiroz, Universidade de São Paulo.

ROBLEDO,F.P., MARTIN,L.V. Aplicación de los plásticos en la agricultura. Madrid: MundiPrensa, 1981, 552p.

SAS INSTITUTE. Statistical Analysis System: realease 6.08, (software). Cary, 1992. 620p.

SCATOLINI, M.E. Estimativa da evapotranspiração da cultura de crisântemo em estufa a partir de elementos meteorológicos. Piracicaba, 1996. 71p. Dissertação (Mestrado) - Escola Superior de Agricultura "Luiz de Queiroz", Universidade de São Paulo.

SEEMANN, J. Greenhouse climate. In: Seemann, J. Agrometeorology. New York: SpringerVerlag, 1979, p.165-178.

SEMEDO, C.M.B. A intensificação da produção hortícola. 3.ed. Mem Martins: Europan, 1988. 192p.

SENTELHAS P. C.; VILLA NOVA, N.A.; ANGELOCCI, R.L. Efeito de diferentes tipos de 
cobertura, em mine estufas, na atenuação da radiação solar e da luminosidade In: CONGRESSO BRASILEIRO DE AGROMETEOROLOGIA 10; Piracicaba, 1997. Anais. Piracicaba: Sociedade Brasileira de Agrometeorologia, 1997. p. 480-484.

SENTELHAS, P. C., SANTOS, A. O., Cultivo Protegido: Aspectos Microclimáticos. Revista Brasileira de Horticultura Ornamental, v.1, n.2, p. 108-115, 1995.

SENTELHAS, P. C.; BORSATTO, R. S.; MINAMI, K. Transmissividade da radiação solar em estufas cobertas com filmes de PVC azul e transparente. Revista Brasileira de Agrometeorologia, v.7, n.2, p.157-162, 1999.

SGANZERLA, E. Nova Agricultura: A fascinante arte de cultivar com os plásticos. 6.ed. Porto Alegre: Petroquímica Triunfo, 1995. 341p.

TANAKA, M.; GENTA, H. Control del medio ambiente bajo invernadero y tunel plastico. Salto, Uruguai: Estación Experimental de Citricultura, 1982. 61p.

TIVELLI, S. W. Manejo do Ambiente em Cultivo Protegido. In: GOTO, R., TIVELLI, S. W. (Coord.) Produção de Hortaliças em Ambiente Protegido: condições subtropicais. São Paulo: Fundação Editora da UNESP, 1998. 319p.

VERLODT, I.; WAAIJENBERG, D., A greenhouse film primer. Batavia, USA: Flora Culture International. Maio, 2000, p.32-33.

VIANA, T. V. A., Evapotranspiração obtida com o sistema razão de bowen e um lisímetro de pesagem em ambiente protegido. Piracicaba, 2000. 137p. Tese (Doutorado) - Escola Superior de Agricultura "Luiz de Queiroz", Universidade de São Paulo. 